Atmos. Chem. Phys., 13, 3909-3929, 2013

www.atmos-chem-phys.net/13/3909/2013/

doi:10.5194/acp-13-3909-2013

(c) Author(s) 2013. CC Attribution 3.0 License.

\title{
Uncertainties in modelling heterogeneous chemistry and Arctic ozone depletion in the winter 2009/2010
}

\author{
I. Wohltmann ${ }^{1}$, T. Wegner ${ }^{2}$, R. Müller ${ }^{2}$, R. Lehmann ${ }^{1}$, M. Rex ${ }^{1}$, G. L. Manney ${ }^{3,4}$, M. L. Santee ${ }^{5}$, P. Bernath ${ }^{6,7}$, \\ O. Sumińska-Ebersoldt ${ }^{8}$, F. Stroh ${ }^{2}$, M. von Hobe ${ }^{2}$, C. M. Volk ${ }^{9}$, E. Hösen ${ }^{9}$, F. Ravegnani ${ }^{10}$, A. Ulanovsky ${ }^{11}$, and \\ V. Yushkov ${ }^{11}$ \\ ${ }^{1}$ Alfred Wegener Institute for Polar and Marine Research, Potsdam, Germany \\ ${ }^{2}$ Institute of Energy and Climate Research - Stratosphere (IEK-7), Forschungszentrum Jülich, Jülich, Germany \\ ${ }^{3}$ NorthWest Research Associates, Inc., Socorro, New Mexico, USA \\ ${ }^{4}$ New Mexico Institute of Mining and Technology, Socorro, New Mexico, USA \\ ${ }^{5}$ Jet Propulsion Laboratory, California Institute of Technology, Pasadena, California, USA \\ ${ }^{6}$ University of York, York, UK \\ ${ }^{7}$ Old Dominion University, Norfolk, VA, USA \\ ${ }^{8}$ Institute of Meteorology and Climate Research, Karlsruhe Institute of Technology, Karlsruhe, Germany \\ ${ }^{9}$ University of Wuppertal, Department of Physics, Wuppertal, Germany \\ ${ }^{10}$ ISAC-CNR, Bologna, Italy \\ ${ }^{11}$ Central Aerological Observatory, Dolgoprudny, Russia
}

Correspondence to: I. Wohltmann (ingo.wohltmann@awi.de)

Received: 13 September 2012 - Published in Atmos. Chem. Phys. Discuss.: 5 October 2012

Revised: 12 March 2013 - Accepted: 24 March 2013 - Published: 17 April 2013

\begin{abstract}
Stratospheric chemistry and denitrification are simulated for the Arctic winter 2009/2010 with the Lagrangian Chemistry and Transport Model ATLAS. A number of sensitivity runs is used to explore the impact of uncertainties in chlorine activation and denitrification on the model results. In particular, the efficiency of chlorine activation on different types of liquid aerosol versus activation on nitric acid trihydrate clouds is examined. Additionally, the impact of changes in reaction rate coefficients, in the particle number density of polar stratospheric clouds, in supersaturation, temperature or the extent of denitrification is investigated. Results are compared to satellite measurements of MLS and ACE-FTS and to in-situ measurements onboard the Geophysica aircraft during the RECONCILE measurement campaign. It is shown that even large changes in the underlying assumptions have only a small impact on the modelled ozone loss, even though they can cause considerable differences in chemical evolution of other species and in denitrification. Differences in column ozone between the sensitivity runs stay below $10 \%$ at the end of the winter. Chlorine activation on liquid aerosols alone is able to explain the ob-
\end{abstract}

served magnitude and morphology of the mixing ratios of active chlorine, reservoir gases and ozone. This is even true for binary aerosols (no uptake of $\mathrm{HNO}_{3}$ from the gas-phase allowed in the model). Differences in chlorine activation between sensitivity runs are within $30 \%$. Current estimates of nitric acid trihydrate (NAT) number density and supersaturation imply that, at least for this winter, NAT clouds play a relatively small role compared to liquid clouds in chlorine activation. The change between different reaction rate coefficients for liquid or solid clouds has only a minor impact on ozone loss and chlorine activation in our sensitivity runs.

\section{Introduction}

After the discovery of the Antarctic ozone hole (Farman et al., 1985), the rapid development of a robust theory of anthropogenic ozone depletion was a great scientific achievement. Since then, many aspects of this theory have been confirmed in a great number of modelling and observational studies (e.g. Solomon, 1999; WMO, 2011). However, 
uncertainties in theory and observations of polar ozone depletion and limitations in quantitatively modelling the complex processes in Chemistry and Transport Models (CTMs) remain an important issue. This is especially true for the microphysics and chemistry of Polar Stratospheric Clouds (PSCs) (e.g. Lowe and MacKenzie, 2008; Peter and Grooß, 2012). The discussion here focusses on the following issues:

- There is currently a debate on the importance of heterogeneous reactions on cold binary aerosol for polar chlorine activation and subsequent ozone loss (e.g. Drdla, 2005; Solomon, 2010; Drdla and Müller, 2012; Solomon, 2012). In 2005, K. Drdla put forward the hypothesis that the generally accepted mechanism of dominant chlorine activation on stratospheric clouds composed of nitric acid trihydrate (NAT) or supercooled ternary solutions (STS) might not be necessary for efficient chlorine activation and that heterogeneous activation of chlorine reservoir species might very efficiently occur already on the cold background aerosol (e.g. Drdla, 2005; Drdla and Müller, 2012). This concept goes somewhat beyond earlier conclusions that some chlorine activation might already occur on binary aerosol particles (e.g. Hanson et al., 1994; Cox et al., 1994). In fact, it is largely unknown to what extent liquid aerosols contribute to chlorine activation in relation to NAT clouds in the atmosphere. A change in this ratio could have important implications for the prediction of future ozone depletion in model scenarios. Drdla's hypothesis is supported by the current low estimates of NAT number density (e.g. Northway et al., 2002; Voigt et al., 2005; Pitts et al., 2009), the required high supersaturation of $\mathrm{HNO}_{3}$ over NAT (e.g. Dye et al., 1990, 1992; Wagner et al., 2005) and the large uncertainties in reaction rates on NAT (Carslaw et al., 1997), which we will discuss in detail later.

- Reaction rate coefficients on liquid aerosols and gassurface reaction probabilities on solid stratospheric cloud particles are poorly constrained. Here, we compare the parameterisation on liquid aerosols which is based on laboratory studies by Hanson and Ravishankara (1994) to the rates of Shi et al. (2001) and the parameterisation of Carslaw et al. (1997) on NAT clouds (based on on laboratory studies by Hanson and Ravishankara, 1993) to the alternative parameterisation from the same paper based on the studies of Abbatt and Molina (1992).

- Additionally, we consider several other uncertainties, including the number density of NAT cloud particles, the required supersaturation for NAT formation, the impact of a possible temperature bias in the meteorological analyses used to force the model runs and the impact of denitrification on ozone depletion.
The RECONCILE project was initiated to help resolving these uncertainties and aims at a better quantitative understanding of the dynamical, chemical and microphysical processes influencing polar ozone depletion (von Hobe et al., 2012). As a part of the project, the first major measurement campaign in the Arctic winter stratosphere since the SOLVE/THESEO campaign in 1999/2000 (Newman et al., 2002) and VINTERSOL-EUPLEX campaign in 2002/2003 (e.g. von Hobe et al., 2005) was conducted in 2009/2010 (a complete list of the meaning of acronyms and abbreviations can be found in Appendix A).

Here, we use runs of the global Chemistry and Transport Model ATLAS (Wohltmann and Rex, 2009; Wohltmann et al., 2010) to give an overview over the chemical evolution of the winter 2009/2010 and to assess the impact of the major uncertainties in the model formulation on the chemical results of the model. This winter was selected due to the large number of datasets available from the campaign for comparison in this winter.

Results are extensively compared to satellite observations of trace species by the MLS instrument onboard the Aura satellite (Waters et al., 2006) and by the ACE-FTS instrument onboard the SCISAT-1 satellite (Bernath et al., 2005). Additionally, in-situ measurements onboard the Geophysica aircraft and ozone sonde ascents conducted during the campaign are used for the comparison (von Hobe et al., 2012). The Supplement includes all comparisons to measurements performed in the framework of this study. The paper shows only a representative selection.

In a related study, Wegner et al. (2012) validate the heterogeneous chemistry parameterisations with in-situ measurements of $\mathrm{ClO}$ from 2005 and 2010 and show that activation on cold background aerosol is sufficient to explain the measurements. In addition, they show that there is no correlation between chlorine activation and the formation of PSCs (depletion of gas-phase $\mathrm{HNO}_{3}$ ) in MLS data.

\section{The model}

\subsection{Model overview}

ATLAS is a global Chemistry and Transport Model (CTM) based on a Lagrangian (trajectory-based) approach. A detailed description of the model can be found in Wohltmann and Rex (2009) and Wohltmann et al. (2010). Transport and chemistry in the model are driven by reanalysis data of the European Centre for Medium-Range Weather Forecasts (ECMWF). A large number of trajectories is initialised and advected with this input. Chemistry is simulated on every trajectory as in a box model. An important feature of the model is the mixing algorithm (Konopka et al., 2004; Wohltmann and Rex, 2009), which simulates atmospheric mixing and diffusion based on a physical approach using properties of the wind fields (i.e., shear and strain). This approach 
is necessary in Lagrangian models (which, unlike Eulerian models, show no numerical diffusion), and allows for a realistic simulation of atmospheric diffusion by tuning the algorithm to observations.

The model includes a gas phase stratospheric chemistry module, heterogeneous chemistry on PSCs and a particlebased Lagrangian denitrification module. The chemistry module comprises 47 active species and more than 180 reactions. The chemistry module is updated compared to Wohltmann et al. (2010). New reactions are shown in Table $1 . \mathrm{Br}_{2}$ is added as a new species. Absorption cross sections and rate coefficients are taken from recent JPL recommendations (Sander et al., 2011), except for the $\mathrm{Cl}_{2} \mathrm{O}_{2}$ photolysis, which is from Burkholder et al. (1990). The values recommended by JPL (Papanastasiou et al., 2009) give very similar results.

\subsection{The heterogeneous chemistry module}

The heterogeneous chemistry module includes 30 different reactions on binary and ternary solutions, nitric acid trihydrate clouds and ice clouds (see Table 2). 14 reactions are added compared to Wohltmann et al. (2010).

The existence and composition of ternary solutions is calculated according to Carslaw et al. (1995). Ternary solutions are formed only if no ice clouds exist. NAT or ice particles form if the saturation mixing ratios of $\mathrm{HNO}_{3}$ over NAT or $\mathrm{H}_{2} \mathrm{O}$ over ice exceed a given supersaturation. Saturation mixing ratios are calculated from the expressions in Hanson and Mauersberger (1988) for NAT and Marti and Mauersberger (1993) for ice. NAT particles are assumed to form from the ternary solution droplets (see Sect. 4 for a discussion). The number density of the droplets and the available $\mathrm{H}_{2} \mathrm{SO}_{4}$ is adjusted accordingly. Water ice clouds form in addition to NAT clouds if the given supersaturation of $\mathrm{H}_{2} \mathrm{O}$ over ice is exceeded.

All particle types form instantly in equilibrium and are assumed to have a constant predefined number density. A uniform particle radius and a surface area density are calculated from the number density and the amount of $\mathrm{HNO}_{3}$ or $\mathrm{H}_{2} \mathrm{O}$ exceeding the saturation mixing ratio for NAT or ice clouds, respectively. In a similar way, the mean radius of a size distribution is adjusted for ternary solutions. The fractions of $\mathrm{HNO}_{3}, \mathrm{H}_{2} \mathrm{O}$ and $\mathrm{HCl}$ contained in the cloud particles are not available for gas phase reactions.

Technically, NAT clouds are formed before STS in the model, i.e., for conditions above the given supersaturation of $\mathrm{HNO}_{3}$ over NAT, only NAT clouds and no ternary liquid clouds will exist, since the NAT clouds consume the available $\mathrm{HNO}_{3}$. This is probably an overestimation of NAT occurrence, since often, ternary liquids and NAT clouds are observed at the same time (e.g. Pitts et al., 2011; Peter and Grooß, 2012).

The initialisation of liquid $\mathrm{H}_{2} \mathrm{SO}_{4}$ for the background aerosol has changed compared to Wohltmann et al. (2010). $\mathrm{H}_{2} \mathrm{SO}_{4}$ mixing ratios have been reduced to a maximum of
Table 1. List of new gas-phase and photolysis reactions compared to Wohltmann et al. (2010).

\begin{tabular}{lll}
\hline Reaction & & \\
\hline $\mathrm{Br}_{2}+h v$ & $\rightarrow$ & $2 \mathrm{Br}$ \\
$\mathrm{ClO}+\mathrm{ClO}$ & $\rightarrow$ & $2 \mathrm{Cl}+\mathrm{O}_{2}$ \\
$\mathrm{O}+\mathrm{HOBr}$ & $\rightarrow$ & $\mathrm{OH}+\mathrm{BrO}$ \\
$\mathrm{BrO}+\mathrm{BrO}$ & $\rightarrow$ & $\mathrm{Br}_{2}+\mathrm{O}_{2}$ \\
$\mathrm{Br}_{2}+\mathrm{OH}$ & $\rightarrow$ & $\mathrm{HOBr}+\mathrm{Br}$ \\
$\mathrm{Cl}_{2} \mathrm{O}_{2}+\mathrm{OH}$ & $\rightarrow$ & $\mathrm{HOCl}+\mathrm{Cl}+\mathrm{O}_{2}$ \\
\hline
\end{tabular}

$0.12 \mathrm{ppb}$ to make the surface area densities of the model compare better to surface area densities inferred from SAGE II. For this purpose, we fitted the calculated vortex mean surface area densities of the reference run to the CCMVal surface area density climatology (Thomason and Peter, 2006) averaged over January to March of all years between 1997 to 2004 and latitudes north of $70^{\circ} \mathrm{N}$.

Constant values for the gas-surface reaction probabilities $\gamma$ on NAT and ice clouds are employed in the model, with the exception of the reactions $\mathrm{ClONO}_{2}+\mathrm{HCl}$ and $\mathrm{ClONO}_{2}+\mathrm{H}_{2} \mathrm{O}$ on NAT (Table 2). By default, we use the parameterisation scheme 1 in Carslaw et al. (1997), which is based on the laboratory studies of Hanson and Ravishankara (1993). Alternatively, the scheme 2 of Carslaw et al. (1997), which is based on the studies of Abbatt and Molina (1992), can be used.

By default, the reactions $\mathrm{ClONO}_{2}+\mathrm{HCl}$ and $\mathrm{ClONO}_{2}+\mathrm{H}_{2} \mathrm{O}$ on ternary solutions are parameterised according to Shi et al. (2001). Alternatively, the parameterisation of Hanson and Ravishankara (1994) can be used. Note that Shi et al. (2001) is the current JPL recommendation (Sander et al., 2011). The parameterisation of Shi et al. (2001) is valid for binary aerosols only and is extended to ternary solutions as described by Wegner et al. (2012).

The denitrification module simulates the nucleation, transport, growth and sedimentation of a large number of PSC particles and is based on the DLAPSE model of Carslaw et al. (2002). Further details about the scheme can be found in Wohltmann et al. (2010).

The model simulates two different modes of NAT particles: A small mode with particles of about $1 \mu \mathrm{m}$ radius on which the heterogeneous reactions take place, but which do not sediment in the model, and a large mode with radii of about $10 \mu \mathrm{m}$ (so called "NAT rocks", Fahey et al., 2001) in the particle module, which does not take part in the chemistry in the model. Here, we assume that the surface area density of the NAT rocks is small enough to be neglected compared to the surface area of the small mode.

\subsection{Model setup}

Model runs are driven by meteorological data from the ECMWF ERA-Interim reanalysis (Dee et al., 2011) on 
Table 2. List of heterogeneous reactions included in the model. The cloud types on which the reactions take place are indicated $($ STS $=$ supercooled ternary solution, NAT $=$ nitric acid trihydrate). The first column shows parameterisations for reaction rate coefficients. The last two columns give gas-surface reaction probabilities $\gamma$ or parameterisations for $\gamma$. Parameterisations are indicated by HR94 = Hanson and Ravishankara (1994) and Hanson et al. (1994), Shi = Shi et al. (2001), HR93 = Hanson and Ravishankara (1993), AM92 = Abbatt and Molina (1992), H96 = Hanson et al. (1996).

\begin{tabular}{|c|c|c|c|c|c|}
\hline Reaction & & & STS & $\gamma$ NAT & $\gamma$ Ice \\
\hline $\mathrm{ClONO}_{2}+\mathrm{H}_{2} \mathrm{O}$ & $\rightarrow$ & $\mathrm{HOCl}+\mathrm{HNO}_{3}$ & HR94/Shi & HR93/AM92 & 0.3 \\
\hline $\mathrm{ClONO}_{2}+\mathrm{HCl}$ & $\rightarrow$ & $\mathrm{Cl}_{2}+\mathrm{HNO}_{3}$ & HR94/Shi & HR93/AM92 & 0.3 \\
\hline $\mathrm{N}_{2} \mathrm{O}_{5}+\mathrm{H}_{2} \mathrm{O}$ & $\rightarrow$ & $\mathrm{HNO}_{3}+\mathrm{HNO}_{3}$ & HR94 & 0.0006 & 0.02 \\
\hline $\mathrm{N}_{2} \mathrm{O}_{5}+\mathrm{HCl}$ & $\rightarrow$ & $\mathrm{ClNO}_{2}+\mathrm{HNO}_{3}$ & - & 0.003 & 0.03 \\
\hline $\mathrm{HOCl}+\mathrm{HCl}$ & $\rightarrow$ & $\mathrm{Cl}_{2}+\mathrm{H}_{2} \mathrm{O}$ & HR94/Shi & 0.1 & 0.2 \\
\hline $\mathrm{BrONO}_{2}+\mathrm{H}_{2} \mathrm{O}$ & $\rightarrow$ & $\mathrm{HOBr}+\mathrm{HNO}_{3}$ & H96 & 0.006 & 0.3 \\
\hline $\mathrm{HOBr}+\mathrm{HCl}$ & $\rightarrow$ & $\mathrm{BrCl}+\mathrm{H}_{2} \mathrm{O}$ & HR94 & 0.1 & 0.3 \\
\hline $\mathrm{ClONO}_{2}+\mathrm{HBr}$ & $\rightarrow$ & $\mathrm{BrCl}+\mathrm{HNO}_{3}$ & - & 0.3 & 0.3 \\
\hline $\mathrm{BrONO}_{2}+\mathrm{HCl}$ & $\rightarrow$ & $\mathrm{BrCl}+\mathrm{HNO}_{3}$ & - & - & 0.3 \\
\hline $\mathrm{HOCl}+\mathrm{HBr}$ & $\rightarrow$ & $\mathrm{BrCl}+\mathrm{H}_{2} \mathrm{O}$ & HR94 & 0.1 & 0.3 \\
\hline $\mathrm{HOBr}+\mathrm{HBr}$ & $\rightarrow$ & $\mathrm{Br}_{2}+\mathrm{H}_{2} \mathrm{O}$ & HR94 & 0.1 & 0.1 \\
\hline $\mathrm{BrONO}_{2}+\mathrm{HBr}$ & $\rightarrow$ & $2 \mathrm{Br}+\mathrm{HNO}_{3}$ & - & - & 0.1 \\
\hline
\end{tabular}

60 model levels $\left(6 \mathrm{~h}\right.$ temporal resolution, $2^{\circ} \times 2^{\circ}$ horizontal resolution). Horizontal model resolution is approximately $150 \mathrm{~km}$ (see Wohltmann and Rex, 2009) and vertical resolution is $1-2 \mathrm{~km}$. The runs use the hybrid pressure-potential temperature coordinate of the model, which is a pure potential temperature coordinate above $100 \mathrm{hPa}$. The vertical motion is driven by diabatic heating rates (clear sky) from ERAInterim. The lower model boundary is at $350 \mathrm{~K}$ potential temperature and the upper boundary at $1900 \mathrm{~K}$. Mixing strength by the critical Lyapunov exponent is set to $3 \mathrm{~d}^{-1}$ (optimal mixing, see Wohltmann and Rex, 2009) and the mixing time step to $12 \mathrm{~h}$. The runs start on 1 November 2009 and end on 31 March 2010. Chemical species are initialised on 1 December to allow for a spin-up in the mixing. Chemical species at the lower and upper boundary are re-initialised every $12 \mathrm{~h}$, as described in Wohltmann and Rex (2009).

In addition to the chemical species, two tracers are included. A passive ozone tracer is initialised with the ozone values of 1 December, but no chemistry acts on the tracer thereafter. The difference between the passive ozone tracer and the chemically active ozone is then a measure for chemical ozone depletion. In an equivalent way, a passive $\mathrm{NO}_{\mathrm{y}}$ tracer is set up by adding up all nitrogen-containing species (except for $\mathrm{N}_{2} \mathrm{O}$ and $\mathrm{N}_{2}$ ). The difference between this tracer and $\mathrm{NO}_{\mathrm{y}}$ is then a measure for denitrification by sedimenting particles.

The number density of NAT particles in the reference run is set to $0.1 \mathrm{~cm}^{-3}$, since this is an upper limit based on the majority of measurements (e.g. Northway et al., 2002; Voigt et al., 2005; Pitts et al., 2009, 2011). For a more detailed discussion, see e.g., Drdla and Müller (2012) or Peter and Grooß (2012). The number density of ice particles is set to $0.01 \mathrm{~cm}^{-3}$ and the number density of the ternary solution droplets to $10 \mathrm{~cm}^{-3}$.
A supersaturation of 10 (corresponding to about $3 \mathrm{~K}$ supercooling) is assumed to be necessary for the formation of the NAT particles. This value is estimated from atmospheric observations (e.g. Dye et al., 1990, 1992; Pitts et al., 2007) and laboratory work (Wagner et al., 2005); for further discussion see e.g., Drdla and Müller (2012) or Peter and Grooß (2012).

The Lagrangian particle model is used to simulate the nucleation, sedimentation, growth and evaporation of large NAT particles. Particles are formed with a nucleation rate of $7.8 \times 10^{-6}$ particles per $\mathrm{h}$ and $\mathrm{cm}^{3}$ (Voigt et al., 2005; Grooß et al., 2005) and an initial radius of $0.1 \mu \mathrm{m}$, wherever the temperature is below the NAT equilibrium temperature.

\subsection{Sensitivity runs}

In addition to the reference run (REF), several sensitivity runs are carried out (Table 3): We explore the hypotheses of Drdla and Müller (2012) with several runs that allow activation only on liquid aerosol, but not on NAT or ice clouds. A run ONLY-LIQ-TER is performed that allows activation only on liquid ternary aerosols, but with everything else unchanged in the heterogeneous chemistry module. That is, the default rates of Shi et al. (2001) are used for liquid aerosols and uptake of $\mathrm{HNO}_{3}$ is allowed. Additionally, we perform a run ONLY-LIQ-TER-HR with activation only on liquid ternary aerosols and the reaction rates of Hanson and Ravishankara (1994) for the reactions $\mathrm{ClONO}_{2}+\mathrm{HCl}$ and $\mathrm{ClONO}_{2}+\mathrm{H}_{2} \mathrm{O}$ on liquid aerosol instead of the default rates from Shi et al. (2001). Finally, we perform a run ONLY-LIQBIN that allows activation only on binary aerosols (no uptake of $\mathrm{HNO}_{3}$ ) and uses the rates of Shi et al. (2001). NAT clouds were switched off in the ONLY-LIQ-TER, ONLY-LIQ-TERHR and ONLY-LIQ-BIN runs as a surrogate for using the very slow reaction rates based on Abbatt and Molina (1992) 
Table 3. Sensitivity runs. Names of the runs and changes with respect to the reference run.

\begin{tabular}{ll}
\hline Name & Description \\
\hline REF & Reference run \\
ONLY-LIQ-TER & Activation only on ternary solutions (No NAT or ice clouds) \\
ONLY-LIQ-TER-HR & As above, but with the reaction rates of Hanson and Ravishankara (1994) for ternary solutions \\
ONLY-LIQ-BIN & Activation only on binary aerosols (no uptake of HNO H $_{3}$ \\
ABBATT & Reaction rates of Abbatt and Molina (1992) for NAT \\
MINUS-ONE-KELVIN & Global temperature offset of -1K \\
NO-DENITRI & No denitrification by sedimenting particles \\
MORE-DENITRI & Increased nucleation rate of NAT rocks (REF x 10) \\
NO-SUPERSAT & No supersaturation of $\mathrm{HNO}_{3}$ over NAT \\
MORE-SUPERSAT & Supersaturation of HNO $\mathrm{H}_{3}$ over NAT of 30 (5 K supercooling) \\
LESS-NATPART & Number density of NAT particles of $0.01 \mathrm{~cm}^{-3}$ (REF / 10) \\
MORE-NATPART & Number density of NAT particles of $1 \mathrm{~cm}^{-3}$ (REF x 10) \\
\hline
\end{tabular}

and prescribing a low NAT surface area density, as done in the "NAT, current" case of Drdla and Müller (2012).

In addition, a run ABBATT with the NAT reaction rates based on Abbatt and Molina (1992) is performed, which uses the same PSC parameterisation as the reference run. This results in the same $\mathrm{HNO}_{3}$ uptake on NAT clouds as in the reference run, but in no heterogeneous activation on NAT due to the low reaction rates. That is, it is expected that the ABBATT run shows similar activation to the ONLY-LIQ-BIN run due to the small $\mathrm{HNO}_{3}$ uptake by liquid aerosols. In the "NAT, current" case of Drdla and Müller (2012), low surface area densities are assumed in addition. These either require very low number densities for NAT $\left(10^{-4} \mathrm{~cm}^{-3}\right.$ or lower) or gas-phase $\mathrm{HNO}_{3}$ and NAT to be in non-equilibrium for higher NAT number densities. Since our equilibrium model always uses all available $\mathrm{HNO}_{3}$ above the NAT saturation mixing ratio to form NAT, the results for the ABBATT run are independent of the NAT number density if the chlorine activation on the NAT clouds is negligible. However, if we had assumed non-equilibrium and higher NAT number densities to obtain the low NAT surface area density, uptake of the additional gas-phase $\mathrm{HNO}_{3}$ by liquids would have produced results similar to the ONLY-LIQ-TER run.

A run with a global temperature offset of $-1 \mathrm{~K}$ is used to study the sensitivity to temperature changes (MINUS-ONEKELVIN). Reaction rates for liquid aerosols show a large sensitivity to temperature changes. A typical order of magnitude for differences between reanalysis temperatures and observations is $1 \mathrm{~K}$. For example, Wegner et al. (2012) show that there is a $1.5 \mathrm{~K}$ bias between ERA-Interim and Geophysica measurements in the polar vortex around $450 \mathrm{~K}$ in March 2005.

A run with the denitrification by sedimentation of large NAT particles switched off (NO-DENITRI), and a run with the nucleation rate of "NAT rocks" multiplied by 10 (MOREDENITRI) explore the sensitivity of the results to the simulated extent of denitrification.
Several runs examine the sensitivity of the results to microphysical parameters, which are still not well known (Peter and Grooß, 2012): a run with no supersaturation required for the formation of NAT particles (NO-SUPERSAT), a run with a supersaturation of 30 ( $5 \mathrm{~K}$ supercooling, MORESUPERSAT), a run with the number density of NAT particles set to $1 \mathrm{~cm}^{-3}(\mathrm{REF} \times 10$, MORE-NATPART $)$, and a run with the number density of NAT particles set to $0.01 \mathrm{~cm}^{-3}$ (REF/10, LESS-NATPART).

We also tested the importance of ice clouds for chlorine activation. The reference run uses a supersaturation of 4 , which effectively switches ice clouds off. A run with no supersaturation (not shown) shows identical results, which suggests that ice clouds play no role for the activation in this winter, even though they were observed in amounts unusual for the Arctic (Pitts et al., 2011).

Several of the sensitivity runs deliberately use unrealistic conditions (e.g., the number density in the MORENATPART run or no denitrification in the NO-DENITRI run) to show that even unrealistic changes do not cause large deviations from the reference run.

Chemistry is only calculated north of $30^{\circ} \mathrm{N}$ latitude for the sensitivity runs to save computing time. South of $30^{\circ} \mathrm{N}$, the mixing ratios are constantly re-initialised with the results of the reference run.

\subsection{Satellite instruments used for initialisation and comparison}

Data from the Microwave Limb Sounder (MLS) instrument on the Aura satellite (Waters et al., 2006) are used to initialise the model and to compare the model results to observations. We use version 3.3 data and follow the guidelines for data screening in Livesey et al. (2011). Table 4 shows altitude resolution, precision and accuracy for all species (Livesey et al., 2011). The altitude resolution for almost all species is about $3 \mathrm{~km}$ and both precision and accuracy are typically in the $10 \%$ range. Since we always show vortex averages of MLS 
Table 4. Altitude resolution and errors of the species measured by MLS. Typical values between $100 \mathrm{hPa}$ and $10 \mathrm{hPa}$ (Livesey et al., 2011).

\begin{tabular}{llll}
\hline Species & Resolution & Precision & Accuracy \\
\hline $\mathrm{ClO}$ & $3-4.5 \mathrm{~km}$ & $0.1 \mathrm{ppb}$ & $0.1 \mathrm{ppb}$ \\
$\mathrm{H}_{2} \mathrm{O}$ & $2-4 \mathrm{~km}$ & $6-10 \%$ & $5-10 \%$ \\
$\mathrm{HCl}$ & $3 \mathrm{~km}$ & $0.2 \mathrm{ppb}$ & $0.2 \mathrm{ppb}$ \\
$\mathrm{HNO}_{3}$ & $3-4 \mathrm{~km}$ & $0.7 \mathrm{ppb}$ & $0.5-1 \mathrm{ppb}$ \\
$\mathrm{N}_{2} \mathrm{O}$ & $4-6 \mathrm{~km}$ & $13-24 \mathrm{ppb}$ & $7-70 \mathrm{ppb}$ \\
$\mathrm{O}_{3}$ & $2.5-3 \mathrm{~km}$ & $0.04-0.1 \mathrm{ppm}$ & $0.05-0.3 \mathrm{ppm}$ \\
\hline
\end{tabular}

data in the following, the statistical error of the averages is negligible and not shown in the following figures. Since the vertical and horizontal resolution of the model are similar to those of the satellite measurements, model and satellite data are compared without taking further measures. More information about the validation of $\mathrm{ClO}$, the most uncertain species, can be found in Santee et al. (2008). ClO data are corrected for the bias mentioned in Santee et al. (2008) and Livesey et al. (2011).

Additionally, version 3.0 data from the Atmospheric Chemistry Experiment Fourier Transform Spectrometer (ACE-FTS) on the SCISAT-1 satellite are used for comparison (Bernath et al., 2005). The vertical resolution of the data is $3-4 \mathrm{~km}$. The instrument measures in solar occultation geometry and the inclination of the orbit is $74^{\circ}$. That means that data density in high latitudes is relatively sparse compared to MLS and that there are no measurements in the polar night. $\mathrm{HCl}$ data generally agrees within 5-10\% (0.2 ppb) with other instruments (Mahieu et al., 2008). Agreement of $\mathrm{ClONO}_{2}$ data with the MIPAS satellite instrument is better than $0.1 \mathrm{ppb}$ (Wolff et al., 2008).

Data from the Halogen Occultation Experiment (HALOE) on the UARS satellite and of the Stratospheric Aerosol and Gas Experiment II (SAGE II) are used for initialisation.

\subsection{Chemical initialisation}

$\mathrm{H}_{2} \mathrm{O}, \mathrm{N}_{2} \mathrm{O}, \mathrm{HCl}, \mathrm{O}_{3}, \mathrm{CO}$ and $\mathrm{HNO}_{3}$ are initialised from all measurements of the MLS instrument performed during 1 December 2009. The location of the air masses sampled by the satellite measurements at the initialisation time of the model (00:00 UTC) is determined by calculating short backward trajectories from the time and location of the satellite measurement to the model initialisation time.

$\mathrm{CH}_{4}$ is initialised from a monthly mean HALOE climatology (mean of the years 1991-2002) as a function of equivalent latitude and pressure (Grooß and Russell III, 2005). All values are multiplied by 1.066 to account for the trend in $\mathrm{CH}_{4}$ (e.g. WMO, 2011). $\mathrm{NO}_{\mathrm{x}}$ is initialised from the monthly mean HALOE dataset by putting all $\mathrm{NO}_{\mathrm{x}}$ into $\mathrm{NO}_{2}$.

$\mathrm{ClONO}_{2}$ is calculated as the difference between $\mathrm{Cl}_{\mathrm{y}}$ and $\mathrm{HCl}$. $\mathrm{Cl}_{\mathrm{y}}$ is taken from a $\mathrm{Cl}_{\mathrm{y}}-\mathrm{N}_{2} \mathrm{O}$ tracer-tracer correlation from ER-2 aircraft and Triple balloon data (Grooß et al., 2002). The reference run and all sensitivity runs show a systematic and persistent bias compared to measurements with this initialisation. That is, less ozone depletion than observed (about $10 \mathrm{DU}$ in the column), less chlorine activation (up to $0.4 \mathrm{ppb}$ less $\mathrm{ClO}$ in sunlit conditions) and more $\mathrm{HCl}$ (up to $0.5 \mathrm{ppb}$ ). A run with $\mathrm{ClONO}_{2}$ taken from measurements of the MIPAS instrument onboard the Envisat satellite on 1 December, with the profiles retrieved by the Oxford L2 processor MORSE (http://www.atm.ox.ac.uk/group/mipas/) gave similar results (not shown in the following). Hence, we increase $\mathrm{ClONO}_{2}$ by $10 \%$ :

$\mathrm{ClONO}_{2}=1.1\left(\mathrm{Cl}_{\mathrm{y}}-\mathrm{HCl}\right)$

$\mathrm{HCl}$ is decreased by the same amount to conserve $\mathrm{Cl}_{\mathrm{y}}$ :

$\mathrm{HCl}_{\text {new }}=\mathrm{HCl}-0.1 \mathrm{ClONO}_{2}$

This leads to a better agreement between measurements and the reference run and all sensitivity runs. However, there is still a moderate underestimation of chlorine activation in all runs. It seems not unlikely that the bias is indeed caused by small differences in the partitioning between $\mathrm{HCl}$ and $\mathrm{ClONO}_{2}$, since small changes in the partitioning have a rather large effect on the results of the model runs and the changes that define the sensitivity runs do not reduce the systematic bias in $\mathrm{HCl}$.

$\mathrm{BrONO}_{2}$ is assumed to contain all $\mathrm{Br}_{\mathrm{y}}$, which is taken from a $\mathrm{Br}_{\mathrm{y}}-\mathrm{CH}_{4}$ relationship from ER-2 aircraft and Triple balloon data in Grooß et al. (2002), with $\mathrm{Br}_{\mathrm{y}}$ deduced from the organic source gases. The obtained $\mathrm{Br}_{\mathrm{y}}$ is scaled by a constant factor to give maximum $\mathrm{Br}_{\mathrm{y}}$ values of $19.9 \mathrm{ppt}$ to agree with Differential Optical Absorption Spectroscopy (DOAS) measurements of BrO (Dorf et al., 2008).

Chlorofluorocarbons and Halons (which have no significant effects on the time scales considered in this study) are initialised as in Wohltmann et al. (2010).

\section{Model results and comparison to observations}

\subsection{Meteorological situation}

In the context of the Arctic stratospheric winters of the last decades, the winter of 2009/2010 was one of the more dynamically disturbed and warm winters. However, the polar vortex experienced an exceptionally cold phase for a short period during January 2010, when the vortex was relatively isolated and stable for several weeks (see also Dörnbrack et al., 2012, for more details on the evolution of the winter and Kuttippurath and Nikulin, 2012, for more information on wave events and stratospheric warmings).

The polar vortex formed in early December 2009 at the $475 \mathrm{~K}$ level, on which we will concentrate here. Already during the formation phase of the vortex, a wave 2 event starting 
on 6 December split the vortex into two parts by 10 December (e.g. Kuttippurath and Nikulin, 2012). The two parts reunited about 10 days later, but mixed in some extra-vortex air. The first temperatures below the NAT equilibrium temperature were observed around 17 December. For the next four weeks, the vortex remained relatively stable and isolated. Temperatures remained low and reached the ice frost point on a synoptic scale around 15 January.

Starting a few days later, the vortex was gradually displaced to Siberia by a developing major warming. The last temperatures below the ice frost point were observed around 25 January. The development of the major warming culminated at the end of January and beginning of February. The warming event was accompanied by a pronounced rise of the temperatures to more than $200 \mathrm{~K}$ almost everywhere in the vortex by mid February. Finally, the vortex was torn into two parts on 11 February. These two parts (one small part located over Canada and a larger part over Siberia) remained surprisingly stable until 1 March, when they were united again. The reunited vortex then remained stable for some weeks and finally dissipated.

Observations by the CALIPSO satellite (Pitts et al., 2011) show only patchy STS/NAT mixtures with low NAT number densities up to the end of December. The first half of January was characterised by widespread STS/NAT mixtures with higher NAT number densities. From 15 January to 21 January, synoptic scale ice clouds were observed, which is rare in the Arctic. The last PSC period, which lasted to the end of January, was dominated by STS clouds.

\subsection{Chlorine activation}

Figure 1 shows the vortex-averaged active chlorine $\left(\mathrm{ClO}_{\mathrm{x}}=\mathrm{ClO}+2 \mathrm{Cl}_{2} \mathrm{O}_{2}\right)$ of the reference run as a function of time and potential temperature. Compared to colder winters, the period of chlorine activation was relatively short. Chlorine activation set in at the end of December and $\mathrm{ClO}_{\mathrm{x}}$ reached maximum values of about $2.1 \mathrm{ppb}$ in the second half of January, when the lowest temperatures were observed. Chlorine was deactivated very quickly during early February, when the major warming set in.

For a quantitative comparison of the modelled $\mathrm{ClO}$ and the ClO observed by the MLS satellite instrument, we calculated backward trajectories starting at the satellite measurements and ending at the time of the last model output before the measurement, since the measurements are taken at times and positions different from the model output and the $\mathrm{ClO}$ lifetime is short. Then, we initialised a chemical box model (based on the same set of reactions as the full model) with the model data and calculated the evolution of the species forward in time to obtain values to compare with the satellite measurements (see Wohltmann et al., 2010, for details).

Figure 2 shows the results for 27 January at $46 \mathrm{hPa}$, the results for additional dates can be found in Sect. 4 (Fig. S17) in the Supplement. The comparison indicates an underesti-

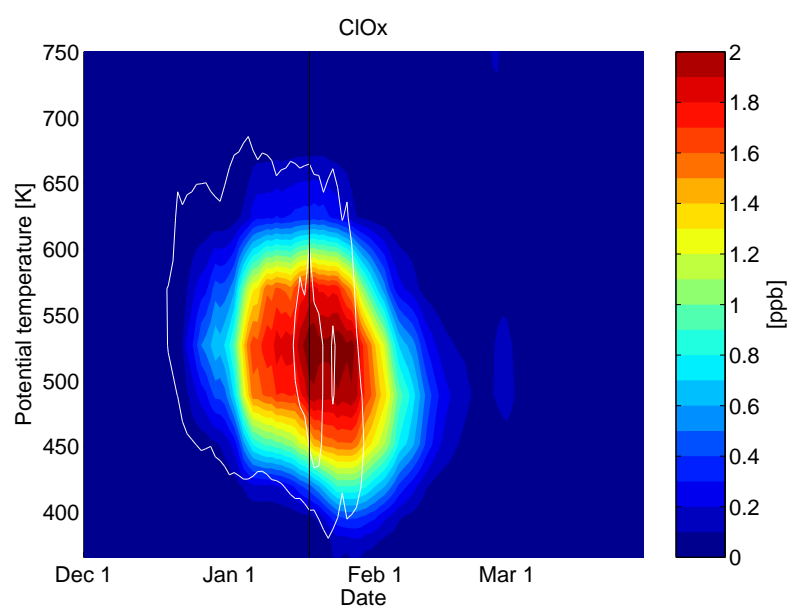

Fig. 1. Vortex-averaged $\mathrm{ClO}_{\mathrm{x}}$ in the reference run as a function of time and potential temperature, averaged over all air parcels inside the vortex boundary according to the Nash criterion (Nash et al., 1996) and over several potential temperature intervals equivalent to the vertical resolution of the model. The Nash criterion is applied at $475 \mathrm{~K}$ and the result is assigned to all other levels (in equivalent latitude). Before 23 December 2009 and after 26 February 2010, the Nash criterion is not applicable and replaced by a constant value of $68.5^{\circ}$ equivalent latitude at all model levels. White contours show the time periods where the formation of NAT clouds (outer contour) and ice clouds (inner contour) was possible inside the vortex. The thin black line shows the date of the profiles in Fig. 4.

mation of $\mathrm{ClO}$ by the model (typically $0.1-0.4 \mathrm{ppb}$ ). This is consistent with an overestimation of the vortex-averaged $\mathrm{HCl}$ of about $0.3 \mathrm{ppb}$ by the model compared to MLS in the same time period and altitude range (see next section). Hence, the underestimation is more likely caused by an underestimation of $\mathrm{ClO}_{\mathrm{x}}$ than by uncertainties in the partitioning between $\mathrm{ClO}$ and $\mathrm{Cl}_{2} \mathrm{O}_{2}$.

The ClO measurements of MLS are corrected as described in Livesey et al. (2011) for the negative bias mentioned in Santee et al. (2008). The remaining uncertainties are around $0.1 \mathrm{ppb}$ and cannot explain the differences between model results and measurements.

However, $\mathrm{ClO}$ measurements of the HALOX instrument (von Hobe et al., 2005; Sumińska-Ebersoldt et al., 2012) onboard the Geophysica agree well with the model results (see Sect. 1, Fig. S7, in the Supplement). Note that these measurements were obtained at about $430 \mathrm{~K}$, where $\mathrm{ClO}$ mixing ratios are smaller. The reason for the large discrepancy between the model and the profile measured on 30 January is unclear.

The comparison of vortex means of the simulated $\mathrm{ClO}$ of the reference run with vortex means of satellite measurements of the MLS instrument in Fig. 3 (1st row) shows that the general morphology is matched well by the model, but that $\mathrm{ClO}$ is underestimated by up to $0.2 \mathrm{ppb}$ on all dates. The vortex means were calculated by applying the same method 

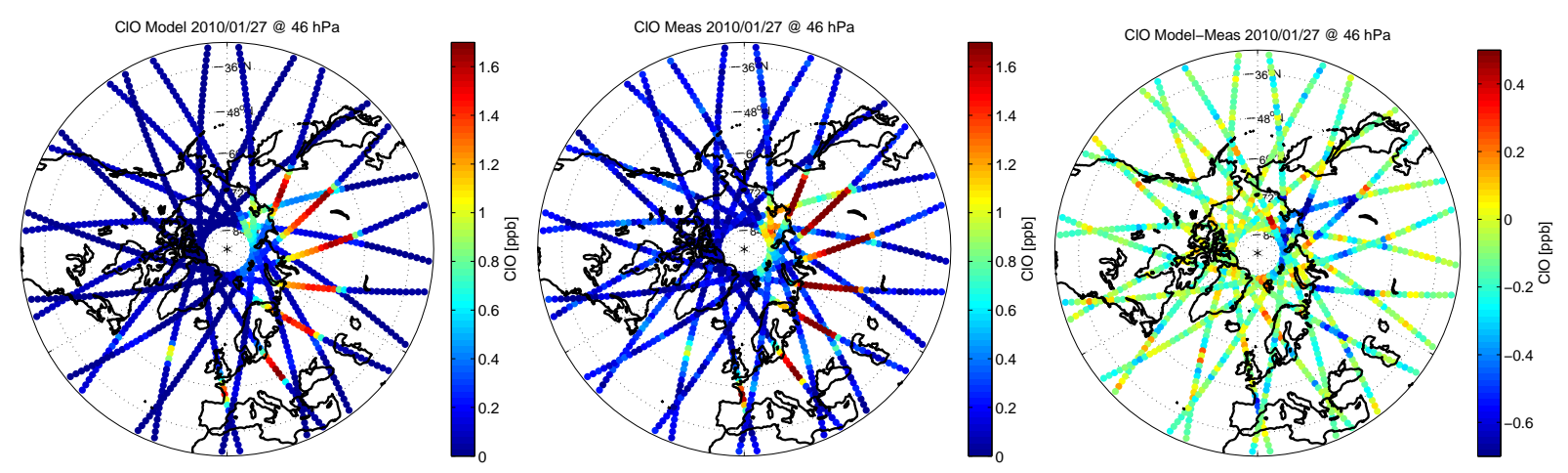

Fig. 2. Modelled (left) and measured (middle) $\mathrm{ClO}$ mixing ratios at the MLS layer centred at $46 \mathrm{hPa}$ along the satellite tracks of $27 \mathrm{January}$. The right panel shows the differences. Backward trajectories starting at the satellite measurements and ending at the time of the last model output before the measurement were calculated. Then, a chemical box model was initialised with the model data and the evolution of the species was calculated forward in time to obtain values to compare with the satellite measurements.

as in Fig. 2 and then averaging over all satellite measurement locations inside the polar vortex. The result is a mean over the vortex values sampled at the satellite measurement locations.

The left panel of Fig. 4 shows the vortex mean chlorine activation in all sensitivity runs and the reference run on 18 January 2010, when all runs show strong activation. The small plots on the right show the same data, but now only a single or two sensitivity runs per plot for clarity. The runs show considerable differences in the absolute amount of chlorine activation at the peak of the profile, ranging from $1.7 \mathrm{ppb}$ for the ONLY-LIQ-BIN run to $2.3 \mathrm{ppb}$ for the MINUS-ONEKELVIN and NO-SUPERSAT runs. The reference run shows an activation of $2.1 \mathrm{ppb}$. The differences between the peak mixing ratios in the sensitivity runs are within $30 \%$.

The runs with activation only on liquid ternary aerosols (ONLY-LIQ-TER and ONLY-LIQ-TER-HR) show almost identical results to the reference run $(2.1 \mathrm{ppb}$ and $2.0 \mathrm{ppb}$, respectively). The shape and also the magnitude of the profiles show that the activation on liquid aerosols alone is efficient enough to explain a large part of the observed chlorine activation and ozone depletion. The Shi et al. (2001) reaction rates in the ONLY-LIQ-TER run cause only a small increase of $0.1 \mathrm{ppb}$ in the chlorine activation compared to the rates of Hanson and Ravishankara (1994) in the ONLY-LIQ-TERHR run.

Chlorine activation in the reference run is almost identical to the ONLY-LIQ-TER run and the MORE-SUPERSAT run (which shows $2.1 \mathrm{ppb}$ ). This suggests that the supersaturation in the reference run and the MORE-SUPERSAT run was so high that almost no NAT clouds formed. Notable differences between the runs with and without NAT clouds can only be achieved by decreasing the supersaturation and increasing the NAT number densities.

The degree of chlorine activation is moderately larger in the runs with no supersaturation (NO-SUPERSAT) and more NAT particles (MORE-NATPART) due to the increased mean surface area density ( $2.3 \mathrm{ppb}$ and $2.2 \mathrm{ppb}$, respectively). The opposite is true for the LESS-NATPART run $(2.0 \mathrm{ppb})$. That is, even large changes in supersaturation and number density, which reach the limits of realistic values in the atmosphere, do only cause changes in chlorine activation in the $10 \%$ range.

The impact of changes in the denitrification on $\mathrm{ClO}_{\mathrm{x}}$ is small on 18 January in the model. Larger differences occur later in winter, when sunlight returns and the deactivation is hindered due to missing $\mathrm{HNO}_{3}$ and $\mathrm{NO}_{\mathrm{x}}$. This can be seen clearly in the comparison of the $\mathrm{ClO}_{\mathrm{x}}$ values of the NODENITRI run and the reference run in Sect. 6 (Fig. S30) in the Supplement. The NO-DENITRI run shows lower $\mathrm{ClO}_{\mathrm{x}}$ values since deactivation into $\mathrm{ClONO}_{2}$ is enhanced compared to the reference run. On 18 January, the NO-DENITRI run shows slightly higher $\mathrm{ClO}_{\mathrm{x}}$ values since more $\mathrm{NO}_{\mathrm{x}}$ is available to regenerate $\mathrm{ClONO}_{2}$, which in turn is needed for the $\mathrm{HCl}+\mathrm{ClONO}_{2}$ heterogeneous reaction.

The MINUS-ONE-KELVIN run shows increased chlorine activation $(2.3 \mathrm{ppb})$ due to the increased occurrence of polar stratospheric clouds and due to the stronger denitrification caused by the lower temperatures.

The ONLY-LIQ-BIN run shows the lowest activation of all sensitivity runs $(1.7 \mathrm{pbb})$ due to the missing uptake of $\mathrm{HNO}_{3}$ into the droplets and the decreased surface area density. But still, the results are of similar magnitude and are able to explain a large part of the observed chlorine activation and subsequent ozone depletion. The ABBATT run shows results similar to the ONLY-LIQ-BIN run (1.9 pbb). This is because $\mathrm{HNO}_{3}$ is depleted from the gas-phase by the NAT clouds, but the reaction rates of Abbatt and Molina (1992) are very low.

It is difficult to decide between the runs with NAT and liquid aerosol and the runs with only liquid aerosol based on the comparisons between the model runs and the comparison of the model to measured species for this winter. However, our results show that it is likely that liquid aerosols play an important role in the activation of chlorine, since NAT clouds 

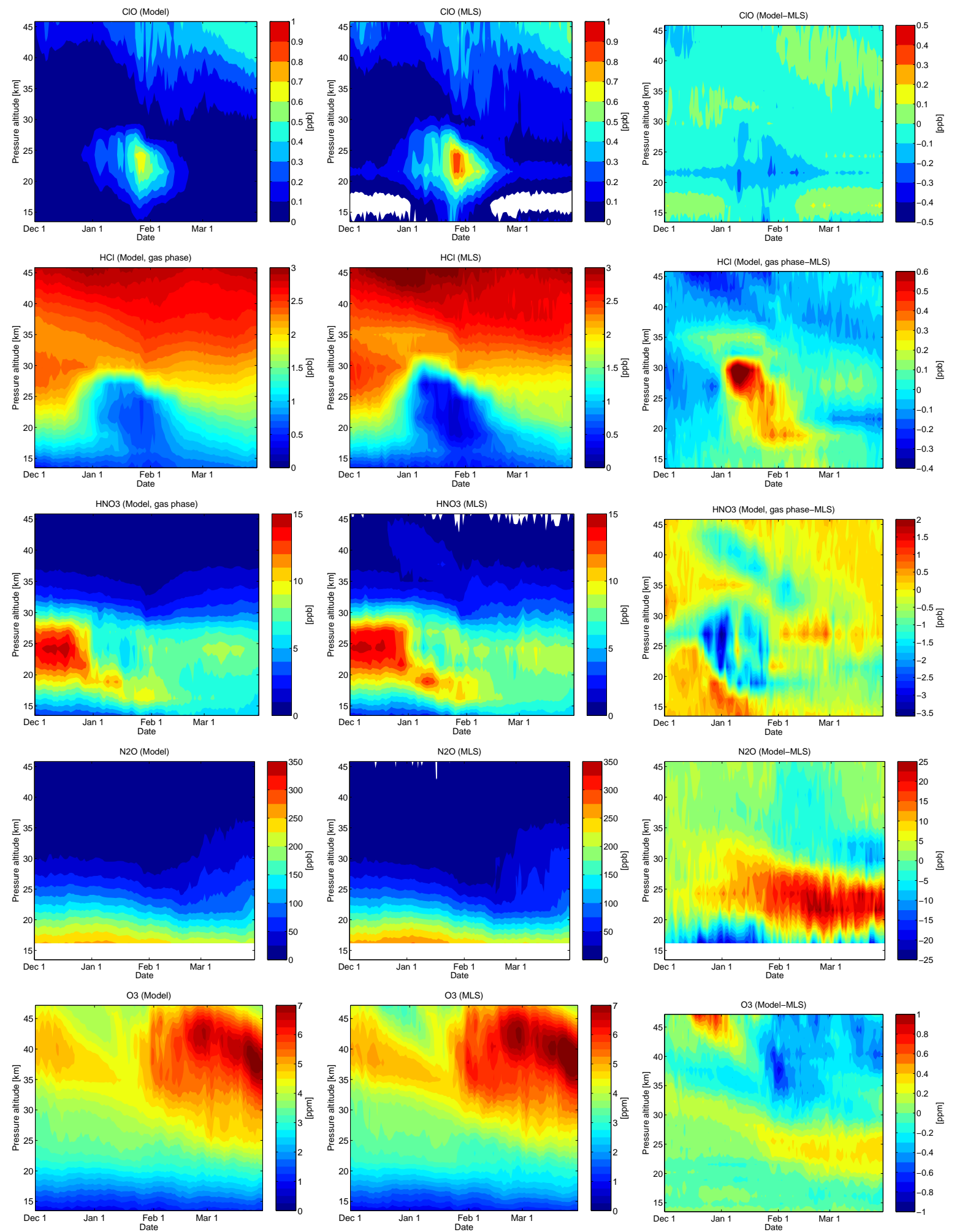

Fig. 3. Comparison of vortex averages of several species between the reference run of the model and MLS satellite measurements. The vortex is sampled at the times and locations of the satellite measurements. Left: vortex-averaged mixing ratio of the model as a function of time and altitude, horizontally averaged as in Fig. 1, vertically averaged in pressure layers centred at the MLS retrieval levels. Middle: same for the MLS measurements. Negative values and missing values are shown in white. Right: difference between model and MLS. Top to bottom: $\mathrm{ClO}, \mathrm{HCl}, \mathrm{HNO}_{3}, \mathrm{~N}_{2} \mathrm{O}, \mathrm{O}_{3}$. 
are of second importance for the activation for current estimates of NAT number density and supersaturation.

Unfortunately, there are no usable measurements of $\mathrm{Cl}_{2} \mathrm{O}_{2}$ for this winter so far, thus, no comparison with measured $\mathrm{ClO}_{\mathrm{x}}$ is possible.

\subsection{Reservoir gases}

The evolution of the modelled $\mathrm{HCl}$ in the reference run compares well to the $\mathrm{HCl}$ observations of MLS morphologically (Fig. 3, 2nd row). However, $\mathrm{HCl}$ is overestimated in the model by about $0.3 \mathrm{ppb}$ in the regions where $\mathrm{HCl}$ is depleted by reactions on PSCs.

Figure 5 shows vortex mean $\mathrm{HCl}$ profiles on 18 January for all sensitivity runs. It is obvious that the overestimation below $550 \mathrm{~K}$ is common to almost all sensitivity runs. A possible reason for the discrepancy could be that the reference initialisation still underestimates the real $\mathrm{ClONO}_{2}$ amount. That would hinder the activation of chlorine by the heterogeneous reaction $\mathrm{ClONO}_{2}+\mathrm{HCl}$ once that $\mathrm{ClONO}_{2}$ had been completely consumed. Further activation would only continue after reformation of $\mathrm{ClONO}_{2}$ by photolysis of $\mathrm{HNO}_{3}$ followed by the reaction $\mathrm{NO}_{2}+\mathrm{ClO}$.

There are other possible reasons for the discrepancies in $\mathrm{HCl}$ and $\mathrm{ClO}$, e.g., a high temperature bias in the ERAInterim reanalysis. A global change of the temperature by $-1 \mathrm{~K}$ in the MINUS-ONE-KELVIN run explains a large part of the discrepancy.

The good agreement between the NO-SUPERSAT run and the observations shows that it cannot be completely excluded that NAT clouds play a greater role in relation to liquid clouds in reality than in our reference run, which shows almost no NAT PSCs. However, the vortex-wide formation of NAT clouds directly below the NAT equilibrium temperature is not supported by observations.

Figure 6 shows vortex mean $\mathrm{ClONO}_{2}$ profiles, which all show very low values below about $525 \mathrm{~K}$, indicating that most available $\mathrm{ClONO}_{2}$ is used up in all sensitivity runs. Above $600 \mathrm{~K}, \mathrm{ClONO}_{2}$ is not depleted. Figure $\mathrm{S} 19$ in Sect. 5 of the Supplement shows that active chlorine is first transformed into $\mathrm{ClONO}_{2}$ starting in February, which is expected under Arctic conditions (e.g. Müller et al., 1994).

Measurements of $\mathrm{ClONO}_{2}$ are made by the ACE-FTS instrument (Bernath et al., 2005). Since ACE-FTS is a solar occultation instrument, measurements are more sparse than for the MLS instrument and are only available for the second half of the winter. In Fig. 7, we show some selected profiles of $\mathrm{ClONO}_{2}$ and $\mathrm{HCl}$ measured inside the vortex on different days in comparison with the model (more species can be found in Sect. 3, Figs. S14-S16, in the Supplement). The agreement of the simulated and observed $\mathrm{ClONO}_{2}$ is quite satisfactory below about $600 \mathrm{~K}$. The ACE measurements of $\mathrm{HCl}$ basically confirm the results of the comparison with MLS data.
Unfortunately, no instrument measures all of the important chlorine species at the same time $\left(\mathrm{HCl}, \mathrm{ClONO}_{2}, \mathrm{ClO}\right.$ and $\mathrm{Cl}_{2} \mathrm{O}_{2}$ ), so that no definitive statements about the agreement of the chlorine loading and the partitioning between active chlorine and reservoir gases in measurements and model can be made.

\subsection{Ozone loss}

Figure 8 shows the vortex-averaged ozone loss as a function of time and potential temperature for the reference run. The largest loss rates are observed in the first half of February, shortly after the largest $\mathrm{ClO}_{\mathrm{x}}$ values. After the warming, ozone loss continues until the end of the model run in March at a slower rate. Even though the vortex splits into two parts in February and is subject to considerable mixing, ozone depleted air remains clearly visible until the end of March in the model. Maximum ozone loss values of $1.4 \mathrm{ppm}$ are reached in the layer between $594 \mathrm{~K}$ and $655 \mathrm{~K}$ inside the vortex by the end of the winter (30 March).

Figure 9 shows the loss profiles for the reference run and all sensitivity runs on 30 March. The differences between the sensitivity runs are within $30 \%(0.2 \mathrm{ppm})$. The potential temperature layer with the largest absolute differences between sensitivity runs is $471 \mathrm{~K}$ to $507 \mathrm{~K}$. Ozone loss values are between $0.78 \mathrm{ppm}$ and $0.94 \mathrm{ppm}$ in this layer. Ozone loss compares well to MLS in this altitude range. Kuttippurath et al. (2010), who modelled ozone loss with passive ozone from the Mimosa-Chim model and MLS data, obtain a similar value of $0.9 \mathrm{ppm}$ here. Above about $600 \mathrm{~K}, \mathrm{NO}_{\mathrm{x}^{-}}$ induced loss begins to dominate (e.g. Konopka et al., 2007), but this region only plays a relatively small role for the column. Note the decrease in $\mathrm{ClO}_{\mathrm{x}}$ in Fig. 1 and the increase in $\mathrm{NO}_{\mathrm{x}}$ in Fig. S18 of the Supplement. Above $600 \mathrm{~K}$, most runs agree well, since the effects of heterogeneous chemistry begin to decrease. The MINUS-ONE-KELVIN run shows lower ozone loss here, since the $\mathrm{NO}_{\mathrm{x}}$ cycle is more effective at higher temperatures.

The maximum ozone loss in the model is underestimated compared to the MLS loss of $1.7 \mathrm{ppm}$ and the altitude of the maximum is overestimated. Note that the ozone loss estimates of the model and MLS are not independent of each other, since both use the same passive profile. It is the same to compare ozone between model and MLS. The discrepancy shows up between $500 \mathrm{~K}$ and $650 \mathrm{~K}$. There are two plausible explanations for this:

- The discrepancy could be caused by differences in dynamics between model and reality. There is a corresponding discrepancy between modelled and measured $\mathrm{N}_{2} \mathrm{O}, \mathrm{N}_{2} \mathrm{O}$ is overestimated in the model. The discrepancies in ozone and $\mathrm{N}_{2} \mathrm{O}$ appear when the major warming sets in at the end of January (see Fig. 3). They could be explained if there was more mixing over the vortex edge in the model (i.e., in ERA-Interim) compared to reality during the major warming. The gradients of $\mathrm{N}_{2} \mathrm{O}$ 


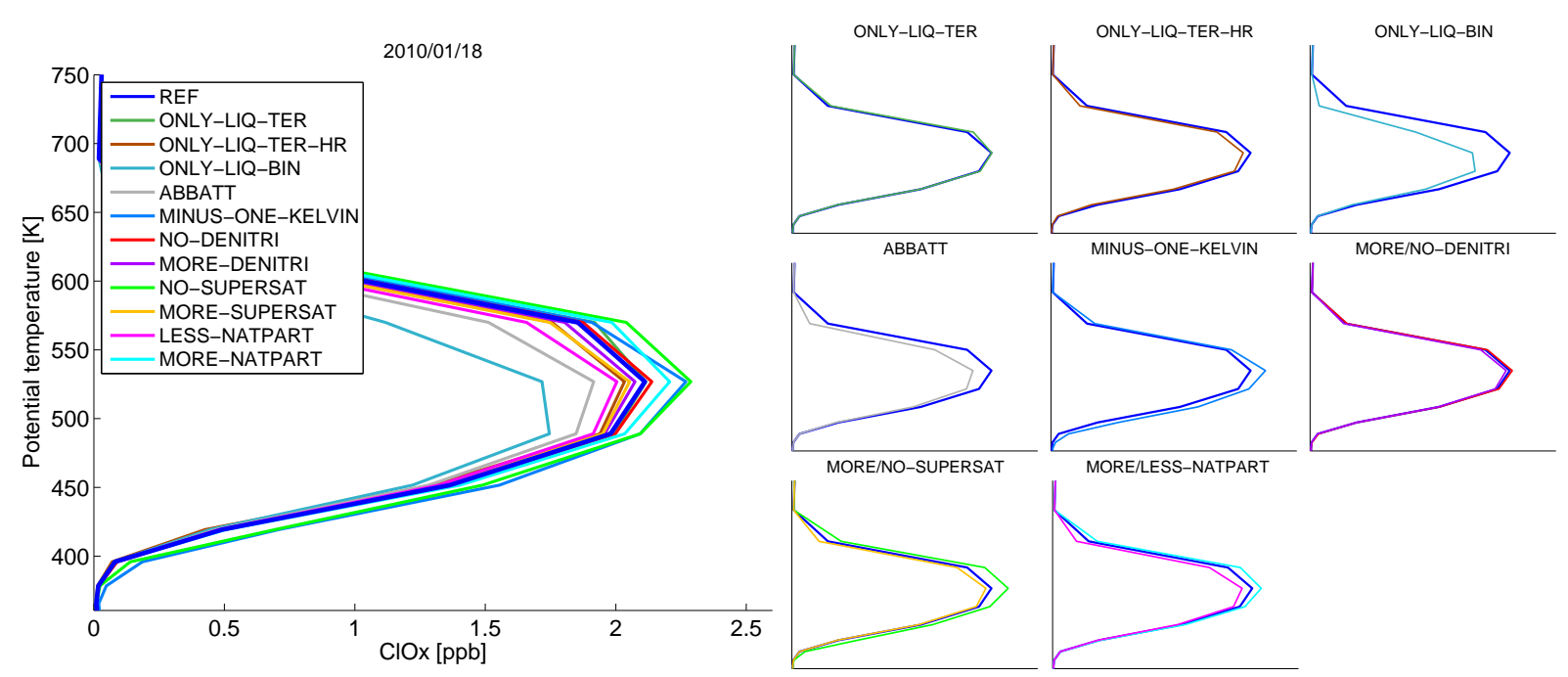

Fig. 4. Vortex-averaged $\mathrm{ClO}_{\mathrm{x}}$ for 18 January 2010 as a function of potential temperature for all sensitivity runs and the reference run. The different sensitivity runs are represented by different colours. Vortex average as in Fig. 1. The small plots on the right show only one or two sensitivity runs and the reference run at the same time for clarity.
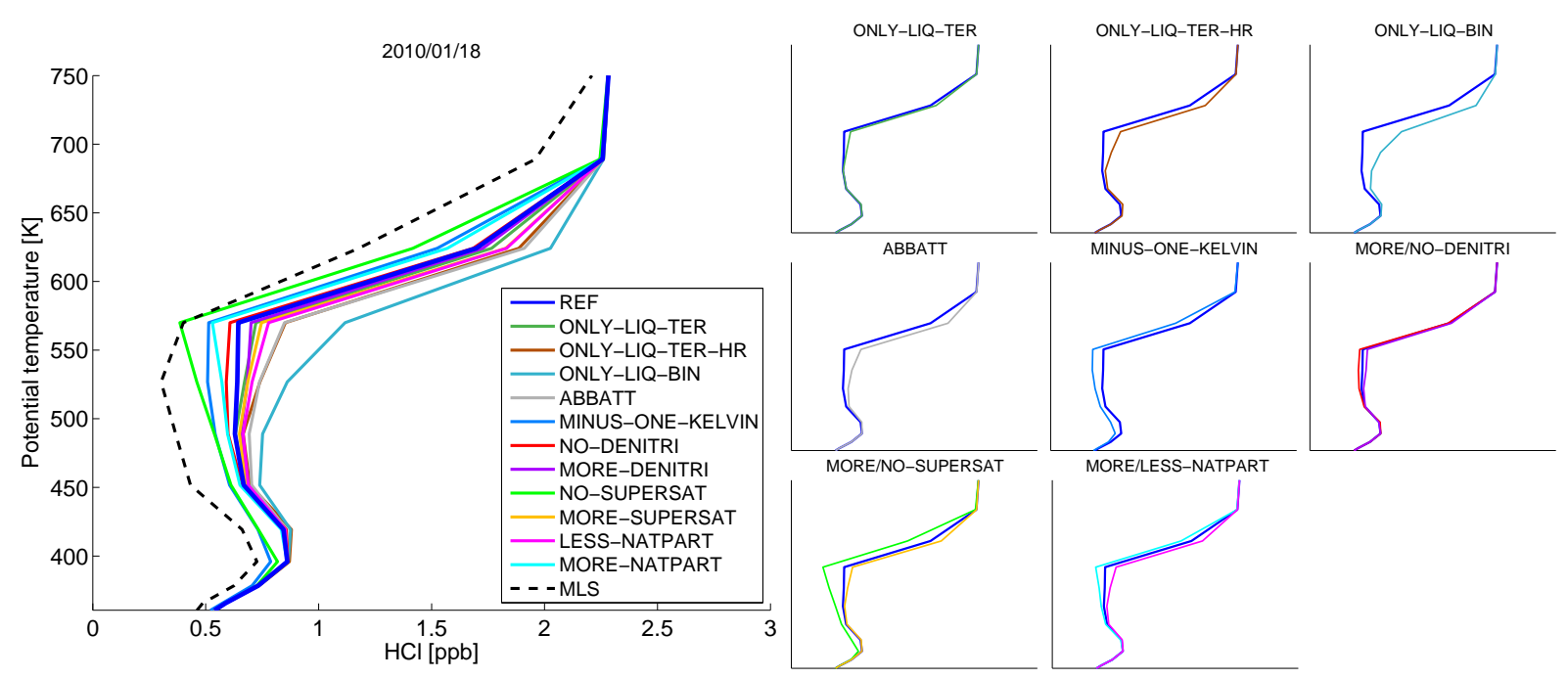

Fig. 5. Vortex-averaged $\mathrm{HCl}$ for 18 January 2010 as a function of potential temperature for all sensitivity runs and the reference run. The different sensitivity runs are represented by different colours. The black dashed line shows corresponding HCl measurements from MLS. Vortex average as in Fig. 1. The small plots on the right show only one or two sensitivity runs and the reference run at the same time for clarity.

and ozone over the vortex edge in this altitude region would be compatible with that. Differences in subsidence can be excluded, since more ozone in the model would imply more subsidence in the model than in reality. However, that would mean less $\mathrm{N}_{2} \mathrm{O}$ in the model, and not more $\mathrm{N}_{2} \mathrm{O}$, as actually modelled.

- Additionally, part of the discrepancy in ozone could be caused by chemistry: There is an overestimation of $\mathrm{HCl}$ and an underestimation of active chlorine in the model in January just in the altitude range where the discrepancy in ozone appears. The life time of ozone between
$500 \mathrm{~K}$ and $650 \mathrm{~K}$ at the end of March is of the order of months, so if the discrepancy is caused by chemistry it must be caused over a longer time period. However, chemistry does not explain the discrepancy in $\mathrm{N}_{2} \mathrm{O}$.

Figure 10 shows the corresponding cumulative loss in the total ozone column of the model for the reference run and all sensitivity runs. The column loss in the reference run on 30 March amounts to 77 DU over the complete simulated column (350-1900 K).

The simulated loss is only moderate compared to the possible range of the cumulative winter ozone losses observed 


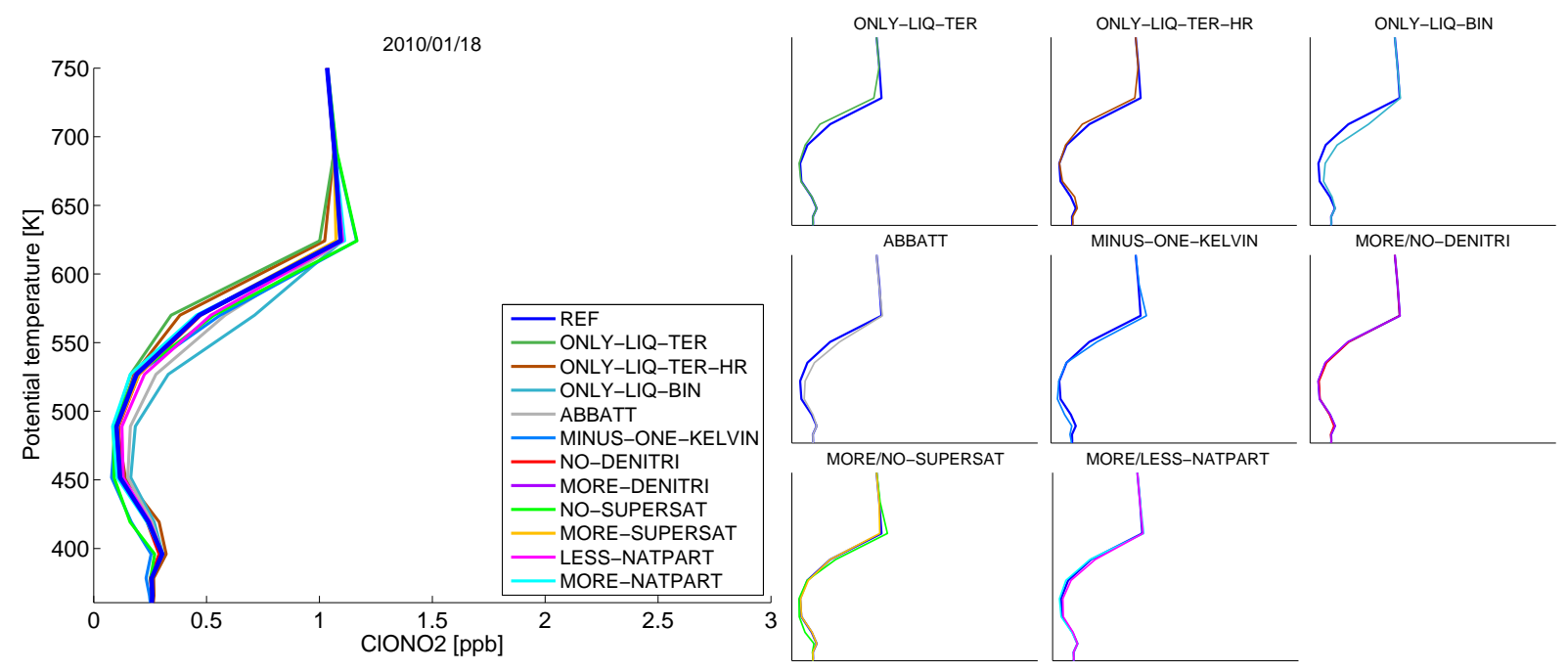

Fig. 6. Vortex-averaged $\mathrm{ClONO}_{2}$ for 18 January 2010 as a function of potential temperature for all sensitivity runs and the reference run. The different sensitivity runs are represented by different colours. Vortex average as in Fig. 1. The small plots on the right show only one or two sensitivity runs and the reference run at the same time for clarity.
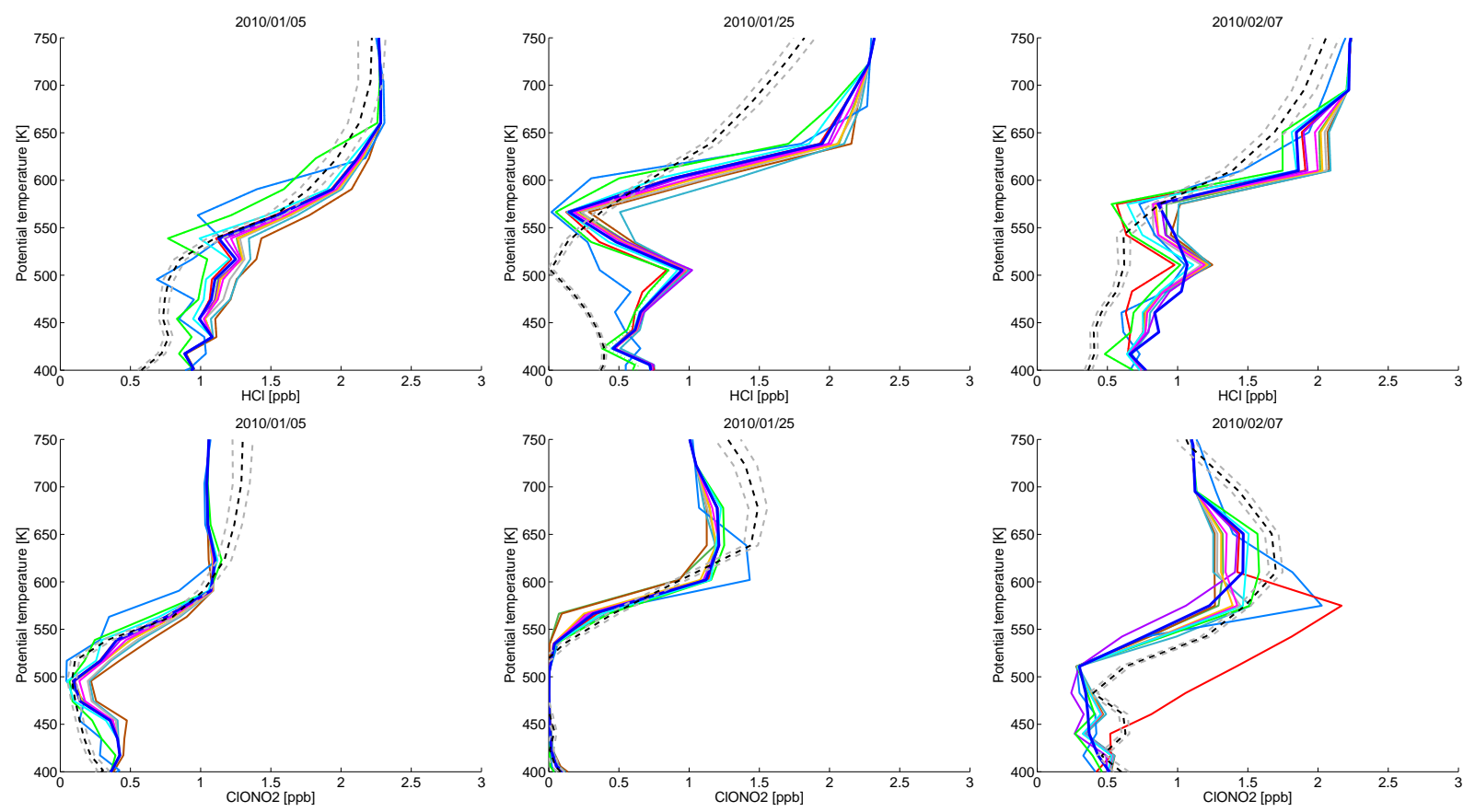

Fig. 7. $\mathrm{HCl}$ and $\mathrm{ClONO}_{2}$ as a function of potential temperature for all sensitivity runs and the reference run for three selected locations in the vortex on different days ( 5 January at $56.8^{\circ} \mathrm{N}$ and $15.1^{\circ} \mathrm{E}, 25$ January at $65.2^{\circ} \mathrm{N}$ and $69.4^{\circ} \mathrm{E}, 7$ February at $67.4^{\circ} \mathrm{N}$ and $29.3^{\circ} \mathrm{E}$ ). Colours indicate the different sensitivity runs (see legend in Fig. 5). The black dashed lines show corresponding measurements from ACE-FTS. The grey dashed lines show the statistical error of the measurements.

in the last decades. For example, the vortex average method, which is based on ozone sondes, shows ozone losses between $20 \mathrm{DU}$ and $130 \mathrm{DU}$ in the partial column from $380-550 \mathrm{~K}$ for the winters from 1991/1992-2010/2011, while our model simulates a loss of $43 \mathrm{DU}$ in the same partial column (the vortex average results are based on an unpublished update of Fig. 3 from Rex et al., 2006, by the authors). The winter with the largest ozone loss so far was the exceptionally cold winter 2010/2011 (see e.g. Manney et al., 2011).

The column ozone loss over the complete simulated column at the end of the winter differs only by a maximum of 7 DU between the sensitivity runs (less than $10 \%$ ), showing 


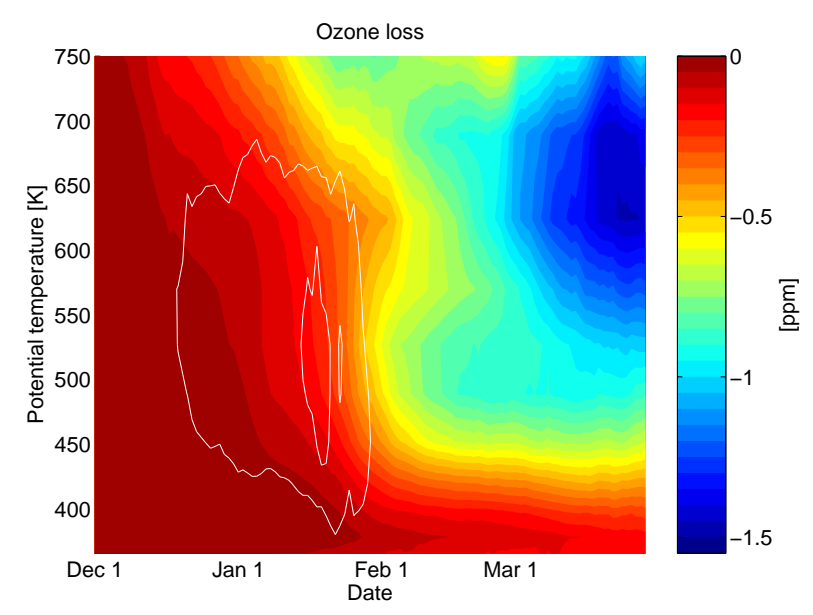

Fig. 8. Vortex-averaged ozone loss for the reference run as a function of time and potential temperature. Difference between the modelled ozone and the passive ozone tracer averaged as in Fig. 1. The white contours show the time periods where the formation of NAT clouds (outer contour) and ice clouds (inner contour) was possible inside the vortex.

that even large changes in the underlying assumptions on heterogeneous chemistry have only a relatively small impact on the modelled column ozone loss.

The differences of the sensitivity runs are to some extent sensitive to the exact procedure of averaging. In particular, taking 1 March as the ending date for the columns would give larger differences (up to $15 \%$ ), since after 1 March, the differences between the sensitivity runs and the reference run in ozone depletion decrease (see the differences of ozone loss between the sensitivity runs and the reference run in Sect. 6 in the Supplement, which peak around 1 March). The decrease is probably caused by our vortex definition, which includes more and more mid-latitude air, since the vortex shrinks faster than we assume.

Likewise, calculating partial columns only up to $600 \mathrm{~K}$ also increases the percentage (up to $13 \%$ on $30 \mathrm{March}$ ), since most of the differences in the sensitivity runs occur below $600 \mathrm{~K}$. Combining both effects gives differences of up to $20 \%$.

Comparison of vortex-averaged model ozone to MLS measurements shows a slight overestimation of ozone by the model in a limited altitude range (Fig. 3, 5th row), in line with the results for $\mathrm{HCl}$ and $\mathrm{ClO}$ of the last subsection. The column ozone loss of 79 DU obtained from MLS by subtracting the passive ozone tracer of the model from the MLS ozone measurements compares well to the modelled loss in most sensitivity runs (see Fig. 10).

Measurements from ozone sondes and from the FOZAN instrument onboard the Geophysica (Ulanovsky et al., 2001) generally show a good agreement with the simulated ozone and also roughly confirm the simulated ozone loss (see Sect. 1, Fig. S8 and Sect. 2, Fig. S13, in the Supplement).

\subsection{Denitrification}

Although the vortex was relatively disturbed (Dörnbrack et al., 2012), pronounced denitrification was simulated by the model in the reference run (see also Khosrawi et al., 2011, for another study on the denitrification in this winter). Denitrification set in at the beginning of January in the model with the low temperatures and reached maximum values of $7.5 \mathrm{ppb}$ in the second half of January (Fig. 11). The air remained denitrified until the end of the model run in March. Below the denitrified layer, a renitrified layer with values of up to $3.3 \mathrm{ppb}$ is simulated.

Figure 12 shows $\mathrm{NO}_{\mathrm{y}}$ (left panel) and $\mathrm{HNO}_{3}$ (right panel) for the reference run and the relevant sensitivity runs on 2 February 2010. 2 February is around the peak of denitrification, but on a day with no uptake of $\mathrm{HNO}_{3}$ by PSCs in the model, which would complicate the comparison. In addition, the CALIPSO satellite instrument shows no PSCs on this day (Pitts et al., 2011). Note that the passive $\mathrm{NO}_{\mathrm{y}}$ tracer is identical to the modelled $\mathrm{NO}_{\mathrm{y}}$ of the NO-DENITRI run (red line), i.e., the difference between the red line and any other line quantifies the denitrification. On this day, the reference run (and all other runs using the nucleation rate of the reference run except for the MINUS-ONE-KELVIN run) shows a denitrification of $7.3 \mathrm{ppb}$ and a renitrification of $3.0 \mathrm{ppb}$, while the MORE-DENITRI run (nucleation rate multiplied by 10) shows $8.8 \mathrm{ppb}$ denitrification and $3.9 \mathrm{ppb}$ renitrification. The MINUS-ONE-KELVIN run shows more denitrification than the reference run since the lower temperatures lead to larger areas below the NAT equilibrium temperature and a faster particle growth.

Comparison with vortex-averaged data of $\mathrm{HNO}_{3}$ by MLS (e.g., for 2 February in the right panel) shows that the runs with the standard nucleation rate of the reference run usually show the best agreement with the measurements. The run with no denitrification is clearly not compatible with the measurements. The MORE-DENITRI run and the MINUSONE-KELVIN run often show lower values than the measurements.

The comparison of the time series of the vortex-averaged $\mathrm{HNO}_{3}$ of the reference run to MLS measurements in Fig. 3 shows that mixing ratios are typically somewhat underestimated by the model (by about $2 \mathrm{ppb}$ ), hinting at a small overestimation of the denitrification by sedimenting particles in the model in the reference run.

\subsection{Long-lived tracers}

A proper simulation of transport and mixing is a prerequisite for a model simulation of high quality. It excludes transport as a source of differences between model and measurement and allows attribution of the differences to e.g., the initialisation or chemistry scheme. A large number of long-lived tracers was measured during the Geophysica flights by the HAGAR instrument (Volk et al., 2000). We will concentrate 

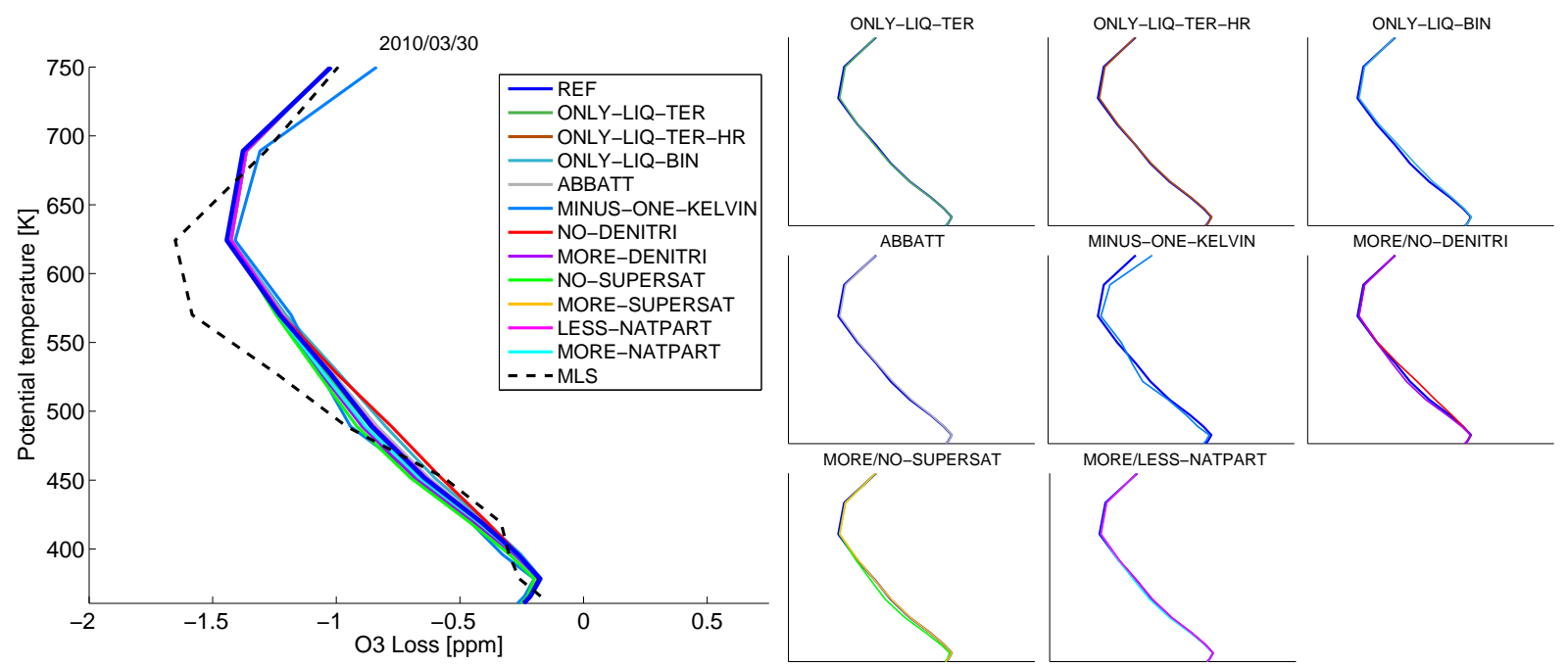

Fig. 9. Vortex-averaged cumulative ozone loss on 30 March 2010 as a function of potential temperature for all sensitivity runs and the reference run. The different sensitivity runs are represented by different colours. The black dashed line shows the corresponding ozone loss obtained by subtracting the passive ozone tracer of the model from MLS ozone measurements. Vortex average as in Fig. 1. The small plots on the right show only one or two sensitivity runs and the reference run at the same time for clarity.

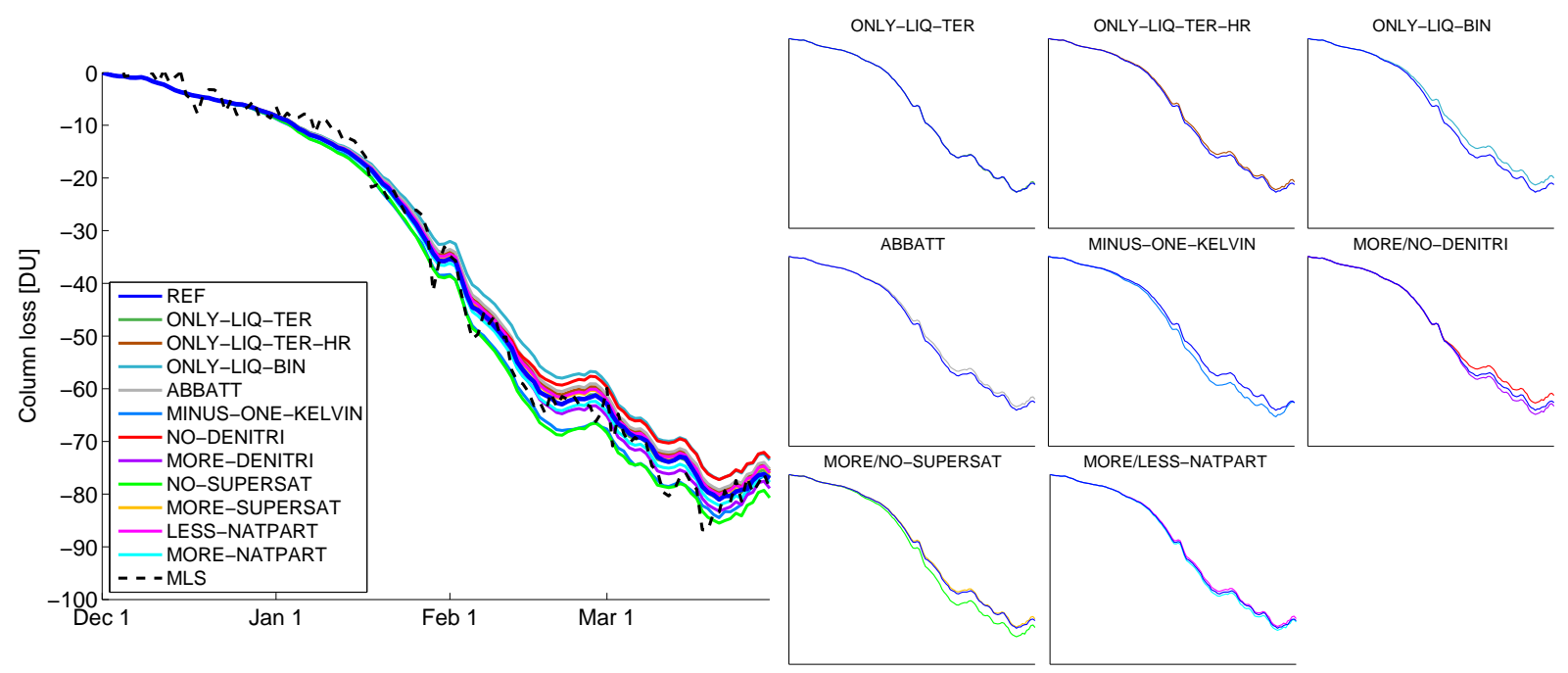

Fig. 10. Vortex-averaged total column ozone loss as a function of time. The different sensitivity runs are represented by different colours. The black dashed line shows the column ozone loss obtained by subtracting the passive ozone tracer of the model from MLS ozone measurements. Vortex average as in Fig. 1. The small plots on the right show only one or two sensitivity runs and the reference run at the same time for clarity.

on $\mathrm{N}_{2} \mathrm{O}$ and $\mathrm{CH}_{4}$ measurements since all tracers basically allow the same conclusions and $\mathrm{N}_{2} \mathrm{O}$ was also measured by MLS.

The tracer measurements from the flights generally show excellent agreement between model results and measurements, indicating no major problems (see Sect. 1, Figs. S9 and S10, in the Supplement). This is supported by the good agreement between model and MLS measurements up to February. Figure 3 shows an overestimation of $\mathrm{N}_{2} \mathrm{O}$ by the model compared to MLS of up to $20 \mathrm{ppb}$ between 20 to
$25 \mathrm{~km}$ in February and March. There are two possible reasons for this: either an underestimation of diabatic descent in the vortex or an overestimation of the in-mixing of air rich in $\mathrm{N}_{2} \mathrm{O}$ from outside the vortex.

Differences in mixing and heating rates between model and reality can cause discrepancies between measurements and model. For example, an overestimation of mixing across the vortex edge would cause lower chlorine values and less ozone loss. It is difficult to quantify how large these effects 


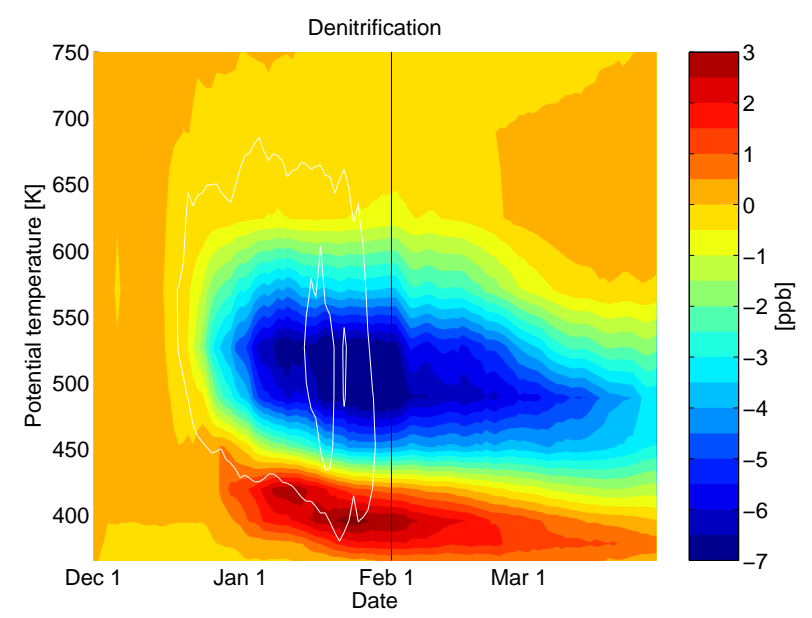

Fig. 11. Vortex-averaged denitrification for the reference run as a function of time and potential temperature. Difference between the passive $\mathrm{NO}_{\mathrm{y}}$ tracer and the modelled $\mathrm{NO}_{\mathrm{y}}$, averaged as in Fig. 1. The thin black line shows the date of the profiles in Fig. 12. The white contours show the time periods where the formation of NAT clouds (outer contour) and ice clouds (inner contour) was possible inside the vortex.

are, since that would require knowledge about the correct mixing and heating rates.

\section{Discussion}

CALIPSO satellite measurements indicate that both STS and NAT clouds were ubiquitous in the Arctic vortex in the winter 2009/2010 (Pitts et al., 2011), with number densities in a broad range from $0.001 \mathrm{~cm}^{-3}$ to $0.1 \mathrm{~cm}^{-3}$ and even higher. In comparison to the other three Arctic winters observed by CALIPSO since 2006/2007, an enhanced number of high density $\left(>0.1 \mathrm{~cm}^{-3}\right)$ STS/NAT mixture clouds was observed in 2009/2010. A peculiarity of this winter was the widespread existence of synoptic-scale ice clouds, which were rarely observed in other Arctic winters by CALIPSO.

CALIPSO observed NAT clouds in significant quantities in this winter. Nevertheless, the runs with activation only or mainly on liquid aerosols (ONLY-LIQ-TER, ONLY-LIQTER-HR, ONLY-LIQ-BIN, ABBATT, MORE-SUPERSAT) show that assuming activation on liquid aerosols only is able to explain the observed magnitude and morphology of the mixing ratios of active chlorine, reservoir gases and ozone. STS clouds were observed virtually during the complete period where PSC formation was possible. In addition, the onset of chlorine activation in late December was dominated by clouds with a very low NAT number density (Pitts et al., 2011). A definitive assessment of how important activation on NAT is compared to activation on liquid aerosols is difficult with our results, since the results for the runs with and without NAT clouds are very similar. Notable differences can only be achieved by increasing the NAT number density and decreasing supersaturation. But even then, the results for the runs with and without NAT clouds are of similar magnitude.

Based on the information from the laboratory studies alone, it is not possible to decide a priori whether the reaction rates of Abbatt and Molina (1992) or Hanson and Ravishankara (1993) on NAT clouds are closer to reality (Carslaw et al., 1997). In addition, due to the small amount of NAT clouds that form in the reference run and the ABBATT run, both runs give relatively similar results. A set of model runs that were performed in preparation of this study and which use a NAT number density of $1 \mathrm{~cm}^{-3}$ and a supersaturation of 4 shows that chlorine activation would be relatively small with the low ABBATT rates, if at the same time NAT clouds in appreciable amounts existed: the uptake of $\mathrm{HNO}_{3}$ by NAT clouds would impede the uptake of $\mathrm{HNO}_{3}$ by binary aerosols and keep their surface area low, while at the same time the NAT clouds would virtually not take part in the activation of chlorine. NAT clouds were clearly observed in significant quantities in this winter, but if our model runs favor the rates of Hanson and Ravishankara (1993) over those of Abbatt and Molina (1992) depends on their surface area relative to the liquid clouds, which is not well known.

Further, it is not possible to discriminate between the rates of Shi et al. (2001) or Hanson and Ravishankara (1994) for liquid aerosols in the model. At least in our model runs for the winter 2009/2010, the change between the rates does not have a great impact on the results.

Our model assumes that NAT clouds are formed from STS droplets. There are considerable theoretical problems with this approach and the formation pathways for NAT are uncertain (Lowe and MacKenzie, 2008; Peter and Grooß, 2012). A possible alternative would be the nucleation of NAT on ice (Lowe and MacKenzie, 2008; Peter and Grooß, 2012). But on the other hand, NAT PSCs have clearly been observed without the prior formation of ice clouds (Voigt et al., 2005; Pitts et al., 2011). In particular, this is also the case for the winter 2009/2010 (Pitts et al., 2011). An inclusion of the ice mechanism into the model would produce less NAT clouds than the current mechanism if only synoptic scale clouds are considered, but could be modified by assuming temperature fluctuations by mountain waves. Another alternative would be heterogenous nucleation on, for example, meteoric material (Lowe and MacKenzie, 2008; Peter and Grooß, 2012). That could be modelled by using the current algorithm, but by switching off the correction for STS number density. This assumption would give very similar results to the original mechanism in the model.

The weak dependence of the results on the number density of NAT particles is not surprising. If a given constant amount of $\mathrm{HNO}_{3}$ is distributed on a variable number $N$ of particles, a simple calculation shows that the corresponding surface area is proportional to $N^{1 / 3}$. That is, increasing the number density by a factor of 10 increases the surface area only by a factor of $10^{1 / 3} \approx 2$. 

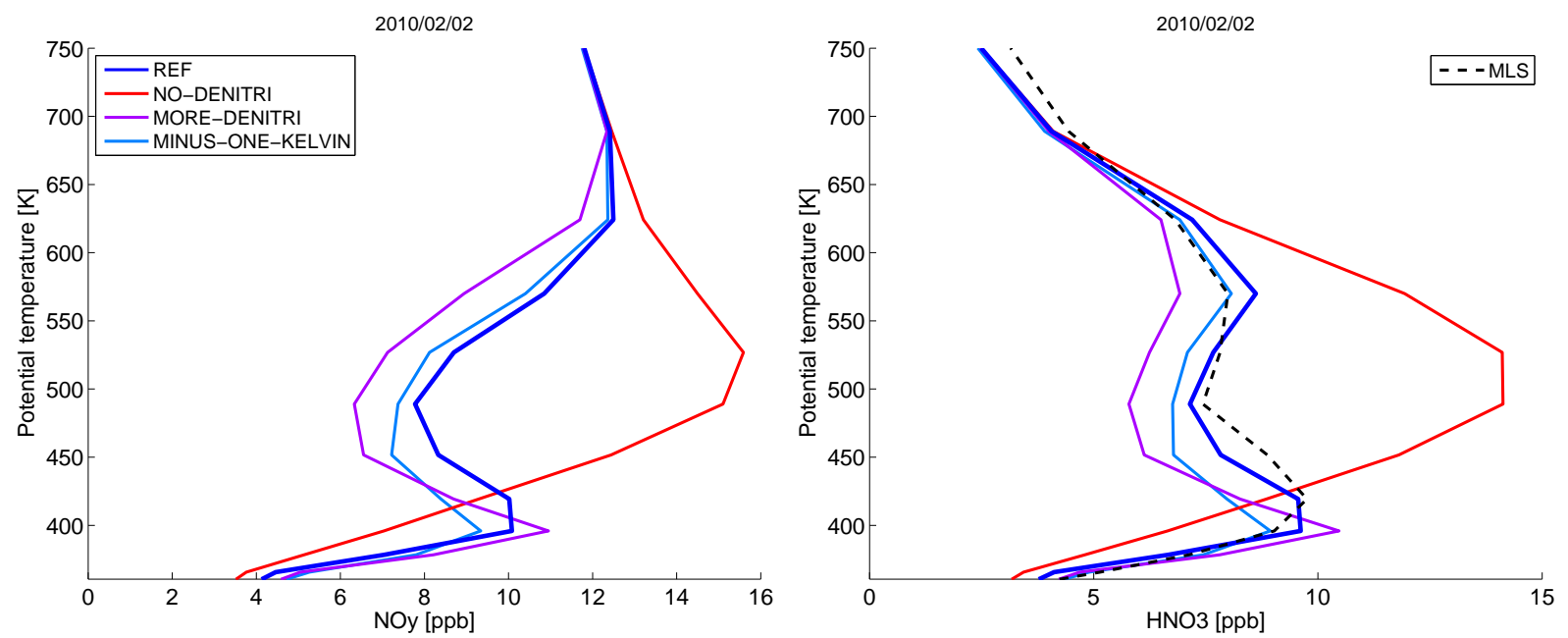

Fig. 12. Vortex-averaged $\mathrm{NO}_{y}$ and $\mathrm{HNO}_{3}$ for 2 February 2010 as a function of potential temperature for the relevant sensitivity runs (reference run REF, run with no denitrification NO-DENITRI and run with the nucleation rate multiplied by 10 MORE-DENITRI). The different

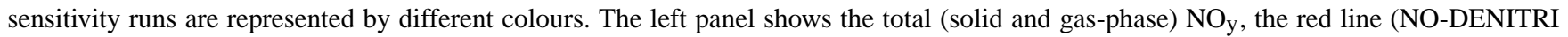
run) is identical to the passive $\mathrm{NO}_{\mathrm{y}}$ tracer. The right panel shows total $\mathrm{HNO}_{3}$ (identical to gas-phase $\mathrm{HNO}_{3}$ on this day). The black dashed line shows corresponding $\mathrm{HNO}_{3}$ measurements from MLS. Vortex average as in Fig. 1.

While the results are quite insensitive to NAT number density, other factors can still cause large discrepancies between model and reality. Important reasons are the unavoidable simplification and idealisation when implementing a heterogeneous chemistry and microphysics module and insufficient constraints by theory and observations. For example, the model assumes an immediate equilibrium, while in reality, the formation and evaporation of cloud particles is a complex non-equilibrium process. This is true in particular for NAT particles, e.g., the time required to condense $50 \%$ of available $\mathrm{HNO}_{3}$ in the gas-phase to NAT particles at a concentration of $10^{-3} \mathrm{~cm}^{-3}$ is several days (Fig. 3 in Drdla and Müller, 2012). In addition, a spatially and temporally constant number density is assumed for NAT, STS and ice, and all particles are assumed to have the same size. In reality, complex mixtures of different particle types, different number densities and different size distributions exist depending on the environmental conditions, air mass history and species concentrations. However, measurements are scarce and the exact formation pathways of cloud particles are still not clear (Lowe and MacKenzie, 2008; Peter and Grooß, 2012). This makes it difficult to constrain the module sufficiently by observations and theory. In addition, the module has to work fast and reliably under all environmental conditions that the model produces.

Note that there is a persistent bias in all sensitivity runs. All runs show somewhat less active chlorine, more reservoir gases and less ozone loss than the observations. However, the relative changes between the runs still provide valuable information that is less affected by the bias. There are several possible factors that could easily explain the bias (a high temperature bias in the analysis, a systematic error in the $\mathrm{ClONO}_{2}$

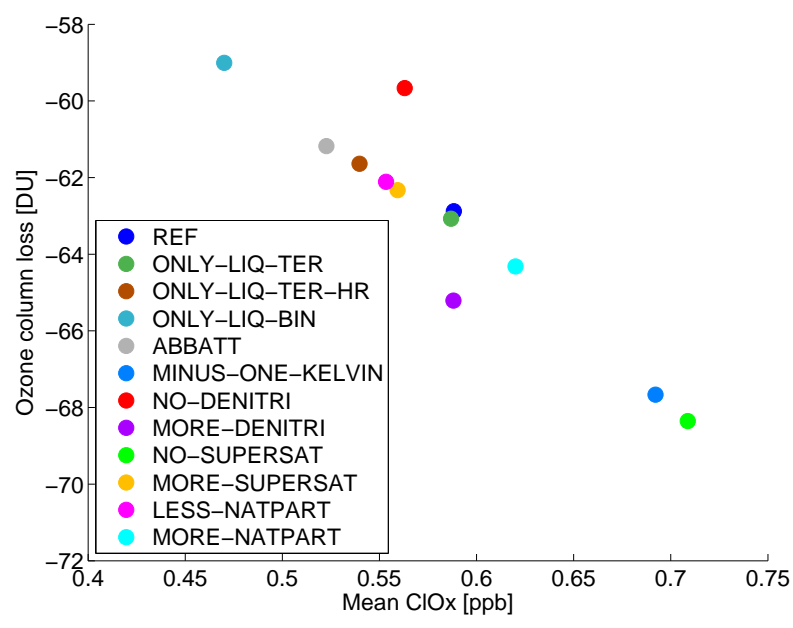

Fig. 13. Extent of chlorine activation versus column ozone loss. Average of vortex mean $\mathrm{ClO}_{\mathrm{x}}$ between 15 December and 15 February and 405 to $655 \mathrm{~K}$ versus vortex mean column ozone loss on 1 March.

initialisation, or a bias in the heating rates or mixing across the vortex edge in the analysis). However, which explanation or combination of explanations is correct is not possible to determine with the available information.

There is a simple reason why all these uncertainties are of secondary importance in the end: Even large changes in the underlying assumptions have only a surprisingly small impact on the modelled column ozone loss on 30 March, which differs by less than $10 \%$ between our sensitivity runs (the percentage increases to $20 \%$ by choosing 1 March as the end date and only a partial column below $600 \mathrm{~K}$ ). The same is 
true for the differences in $\mathrm{ClO}_{\mathrm{x}}$, which are of the same order of magnitude, but somewhat larger (up to $30 \%$ on 18 January). Since it can be expected that ozone loss is roughly linear in $\mathrm{ClO}_{\mathrm{x}}$ (Harris et al., 2010), the differences in ozone loss are well explained by the differences in $\mathrm{ClO}_{\mathrm{x}}$.

There may be several reasons why the sensitivity of ozone loss to the changes seems to be even smaller than the sensitivity of $\mathrm{ClO}_{\mathrm{x}}$ to the changes: first, our vortex definition reduces the differences in ozone depletion between the sensitivity runs in late March, since more and more mid-latitude air is included in the average. Another reason is that the exact timing and altitude dependence of the activation in the Arctic are not important as long as the extent of the chlorine activation is the same in the end. Harris et al. (2010) demonstrate that several processes offset each other, e.g., the altitude dependence of the reaction rates is offset by the altitude dependence of $\mathrm{Cl}_{\mathrm{y}}$ and the initially higher ozone loss rates in case of late activation are offset by faster deactivation. Figure 13 illustrates this very convincingly. The figure shows the mean $\mathrm{ClO}_{\mathrm{x}}$ of the winter versus the column ozone loss on 1 March for all sensitivity runs. There is an almost perfect linear relationship between the mean chlorine activation and the column ozone loss.

\section{Conclusions}

We performed sensitivity runs for the Arctic winter 2009/2010 with the Lagrangian Chemistry and Transport Model ATLAS to explore the impact of uncertainties in chlorine activation and denitrification on the model results, with a particular focus on microphysics and chemistry on polar stratospheric clouds. Our main findings are:

- Even (unrealistically) large changes in the underlying assumptions on chlorine activation have only a small impact on the modelled ozone loss. Changes in column ozone loss stayed below $10 \%$ in our sensitivity runs. This shows that ozone loss is a robust quantity with regard to changes in the microphysical and heterogeneous chemical assumptions.

- Chlorine activation on liquid aerosols alone is sufficient to explain the observed magnitude and morphology of the mixing ratios of active chlorine, reservoir gases and ozone.

- This is even true for cold binary aerosols (no uptake of $\mathrm{HNO}_{3}$ from the gas-phase allowed in the model). However, the runs with ternary aerosols agree better with the observations.

- Current estimates of NAT number density and of the supersaturation of $\mathrm{HNO}_{3}$ over NAT required for NAT formation imply a relatively small role of NAT clouds in chlorine activation, at least for the winter 2009/2010.
- No discrimination between the reaction rates of Shi et al. (2001) or Hanson and Ravishankara (1994) for liquid aerosols is possible from our results. The change between the rates only has a minor impact on the results.

- The same is true for the heterogeneous rates on NAT based on Abbatt and Molina (1992) or Hanson and Ravishankara (1993). However, one of the sensitivity runs with the rates based on Abbatt and Molina (1992) indicates that chlorine activation would be relatively small with these rates, if at the same time NAT clouds in appreciable amounts existed. This is, however, not the case with our default values for supersaturation and number density.

- The timing and altitude dependence of the chlorine activation are not important for the column ozone loss in the model as long as the extent of the chlorine activation $\left(\mathrm{ClO}_{\mathrm{x}}\right.$ mixing ratio averaged over winter and all altitudes) is the same.

The findings in Drdla and Müller (2012) and Wegner et al. (2012) are confirmed by our results. Wegner et al. (2012) show that there is no interannual correlation between the depletion of $\mathrm{HCl}$ and the formation of NAT or STS clouds and that binary aerosol is sufficient to explain the observed chlorine activation for several trajectory case studies in 2005 and 2010.

\section{Appendix A}

\section{List of abbreviations}

Acronym Explanation

\begin{tabular}{ll}
\hline ACE-FTS & $\begin{array}{l}\text { Atmospheric Chemistry Experiment } \\
\text { Fourier Transform Spectrometer } \\
\text { Alfred Wegener Institute Lagrangian } \\
\text { Chemistry/Transport System } \\
\text { Cloud-Aerosol Lidar and Infrared } \\
\text { Pathfinder Satellite Observations } \\
\text { Chemistry-Climate Model Validation Ac- } \\
\text { tivity } \\
\text { CALIPSO }\end{array}$ \\
CCM-Val & $\begin{array}{l}\text { Denitrification by Lagrangian Particle Sed- } \\
\text { imentation }\end{array}$ \\
DLAPSE & $\begin{array}{l}\text { Differential Optical Absorption Spec- } \\
\text { troscopy }\end{array}$ \\
DOAS & $\begin{array}{l}\text { Weather Forecasts } \\
\text { Fast-Response Chemiluminescent Air- } \\
\text { borne Ozone Analyzer } \\
\text { High Altitude Gas Analyzer }\end{array}$ \\
FOZAN &
\end{tabular}




\begin{tabular}{|c|c|}
\hline HALOE & Halogen Occultation Experiment \\
\hline HALOX & Halogen Oxide Monitor \\
\hline JPL & Jet Propulsion Laboratory \\
\hline Mimosa & $\begin{array}{l}\text { Modèle Isentrope du transport Méso- } \\
\text { échelle de l'Ozone Stratosphérique par Ad- } \\
\text { vection }\end{array}$ \\
\hline MIPAS & $\begin{array}{l}\text { Michelson Interferometer for Passive At- } \\
\text { mospheric Sounding }\end{array}$ \\
\hline MLS & Microwave Limb Sounder \\
\hline MORSE & $\begin{array}{l}\text { MIPAS Orbital Retrieval using Sequential } \\
\text { Estimation }\end{array}$ \\
\hline NAT & Nitric Acid Trihydrate \\
\hline PSC & Polar Stratospheric Cloud \\
\hline RECONCILE & $\begin{array}{l}\text { Reconciliation of essential process param- } \\
\text { eters for an enhanced predictability of arc- } \\
\text { tic stratospheric ozone loss and its climate } \\
\text { interactions }\end{array}$ \\
\hline SAGE II & $\begin{array}{l}\text { Stratospheric Aerosol and Gas Experiment } \\
\text { II }\end{array}$ \\
\hline SCISAT & Science Satellite \\
\hline $\begin{array}{l}\text { SOLVE- } \\
\text { THESEO }\end{array}$ & $\begin{array}{l}\text { Stratospheric Aerosol and Gas Experiment } \\
\text { (SAGE) III Ozone Loss and Validation Ex- } \\
\text { periment (SOLVE) and the Third European } \\
\text { Stratospheric Experiment on Ozone (THE- } \\
\text { SEO 2000) }\end{array}$ \\
\hline STS & Supercooled Ternary Solution \\
\hline UARS & Upper Atmosphere Research Satellite \\
\hline VINTERSOL & Validation of International Satellites and \\
\hline EUPLEX & $\begin{array}{l}\text { Study of Ozone Loss - European Polar } \\
\text { Stratospheric Cloud and Lee-wave Exper- } \\
\text { iment }\end{array}$ \\
\hline WMC & World Meteorological Organization \\
\hline
\end{tabular}

\section{Supplementary material related to this article is available online at: http://www.atmos-chem-phys.net/13/ 3909/2013/acp-13-3909-2013-supplement.pdf.}

\section{References}

Abbatt, J. P. D. and Molina, M. J.: Heterogeneous interactions of $\mathrm{ClONO}_{2}$ and $\mathrm{HCl}$ on nitric acid trihydrate at $202 \mathrm{~K}$, J. Phys. Chem., 96, 7674-7679, 1992.

Bernath, P. F., McElroy, C. T., Abrams, M. C., Boone, C. D., Butler, M., Camy-Peyret, C., Carleer, M., Clerbaux, C., Coheur, P.-F., Colin, R., DeCola, P., DeMazière, M., Drummond, J. R., Dufour, D., Evans, W. F. J., Fast, H., Fussen, D., Gilbert, K., Jennings, D. E., Llewellyn, E. J., Lowe, R. P., Mahieu, E., McConnell, J. C., McHugh, M., McLeod, S. D., Michaud, R., Midwinter, C., Nassar, R., Nichitiu, F., Nowlan, C., Rinsland, C. P., Rochon, Y. J., Rowlands, N., Semeniuk, K., Simon, P., Skelton, R., Sloan, J. J., Soucy, M.-A., Strong, K., Tremblay, P., Turnbull, D., Walker, K. A., Walkty, I., Wardle, D. A., Wehrle, V., Zander, R., and Zou, J.: Atmospheric Chemistry Experiment (ACE): Mission overview, Geophys. Res. Lett., 32, L15S01, doi:10.1029/2005GL022386, 2005.

Burkholder, J. B., Orlando, J. J., and Howard, C. J.: Ultraviolet absorption cross sections of chlorine oxide $\left(\mathrm{Cl}_{2} \mathrm{O}_{2}\right)$ between 210 and 410 nm, J. Phys. Chem., 94, 687-695, 1990.

Carslaw, K., Peter, T., and Müller, R.: Uncertainties in reactive uptake coefficients for solid stratospheric particles - 2. Effect on ozone depletion, Geophys. Res. Lett., 24, 1747-1750, 1997.

Carslaw, K. S., Luo, B., and Peter, T.: An analytical expression for the composition of aqueous $\mathrm{HNO}_{3}-\mathrm{H}_{2} \mathrm{SO}_{4}$ stratospheric aerosols including gas phase removal of $\mathrm{HNO}_{3}$, Geophys. Res. Lett., 22, 1877-1880, 1995.

Carslaw, K. S., Kettleborough, J. A., Northway, M. J., Davies, S., Gao, R.-S., Fahey, D. W., Baumgardner, D. G., Chipperfield, M. P., and Kleinböhl, A.: A vortex-scale simulation of the growth and sedimentation of large nitric acid hydrate particles, J. Geophys. Res., 107, 8300, doi:10.1029/2001JD000467, 2002.

Cox, R. A., MacKenzie, A. R., Müller, R. H., Peter, T., and Crutzen, P. J.: Activation of stratospheric chlorine by reactions in liquid sulphuric acid, Geophys. Res. Lett., 21, 1439-1442, 1994.

Dee, D. P., Uppala, S. M., Simmons, A. J., Berrisford, P., Poli, P., Kobayashi, S., Andrae, U., Balmaseda, M. A., Balsamo, G., Bauer, P., Bechtold, P., Beljaars, A. C. M., van de Berg, L., Bidlot, J., Bormann, N., Delsol, C., Dragani, R., Fuentes, M., Geer, A. J., Haimberger, L., Healy, S. B., Hersbach, H., Hólm, E. V., Isaksen, L., Kållberg, P., Köhler, M., Matricardi, M., McNally, A. P., Monge-Sanz, B. M., Morcrette, J.-J., Park, B.-K., Peubey, C., de Rosnay, P., Tavolato, C., Thépaut, J.-N., and Vitart, F.: The ERA-Interim reanalysis: configuration and performance of the data assimilation system, Q. J. Roy. Met. Soc., 137, 553-597, 2011.

Dorf, M., Butz, A., Camy-Peyret, C., Chipperfield, M. P., Kritten, L., and Pfeilsticker, K.: Bromine in the tropical troposphere and stratosphere as derived from balloon-borne $\mathrm{BrO}$ observations, Atmos. Chem. Phys., 8, 7265-7271, doi:10.5194/acp-8-72652008, 2008.

Dörnbrack, A., Pitts, M. C., Poole, L. R., Orsolini, Y. J., Nishii, K., and Nakamura, H.: The 2009-2010 Arctic stratospheric winter general evolution, mountain waves and predictability of an operational weather forecast model, Atmos. Chem. Phys., 12, 36593675, doi:10.5194/acp-12-3659-2012, 2012.

Drdla, K.: Temperature treshold for polar stratospheric ozone, EOS Trans. AGU, 86, Fall Meet., Abstract A31D-03, 2005. 
Drdla, K. and Müller, R.: Temperature thresholds for chlorine activation and ozone loss in the polar stratosphere, Ann. Geophys., 30, 1055-1073, doi:10.5194/angeo-30-1055-2012, 2012.

Dye, J. E., Gandrud, B. W., Baumgardner, D., Chan, K. R., Ferry, G. V., Loewenstein, M., Kelly, K. K., and Wilson, J. C.: Observed particle evolution in the polar stratospheric cloud of January 24, 1989, Geophys. Res. Lett., 17, 413-416, 1990.

Dye, J. E., Baumgardner, D., Gandrud, B. W., Kawa, S. R., Kelly, K. K., Loewenstein, M., Ferry, G. V., Chan, K. R., and Gary, B. L.: Particle size distributions in Arctic polar stratospheric clouds, growth and freezing of sulfuric acid droplets, and implications for cloud formation, J. Geophys. Res., 97, 8015-8034, 1992.

Fahey, D. W., Gao, R. S., Carslaw, K. S., Kettleborough, J., Popp, P. J., Northway, M. J., Holecek, J. C., Ciciora, S. C., McLaughlin, R. J., Thompson, T. L., Winkler, R. H., Baumgardner, D. G., Gandrud, B., Wennberg, P. O., Dhaniyala, S., McKinney, K., Peter, T., Salawitch, R. J., Bui, T. P., Elkins, J. W., Webster, C. R., Atlas, E. L., Jost, H., Wilson, J. C., Herman, R. L., Kleinböhl, A., and von König, M.: The detection of large $\mathrm{HNO}_{3}$-containing particles in the winter Arctic stratosphere, Science, 291, 1026-1031, 2001.

Farman, J. C., Gardiner, B. G., and Shanklin, J. D.: Large losses of total ozone in Antarctica reveal seasonal $\mathrm{ClOx} / \mathrm{NOx}$ interaction, Nature, 315, 207-210, 1985.

Grooß, J.-U. and Russell III, James M.: Technical note: A stratospheric climatology for $\mathrm{O}_{3}, \mathrm{H}_{2} \mathrm{O}, \mathrm{CH}_{4}, \mathrm{NO}_{\mathrm{x}}, \mathrm{HCl}$ and $\mathrm{HF}$ derived from HALOE measurements, Atmos. Chem. Phys., 5, 2797-2807, doi:10.5194/acp-5-2797-2005, 2005.

Grooß, J.-U., Günther, G., Konopka, P., Müller, R., McKenna, D. S., Stroh, F., Vogel, B., Engel, A., Müller, M., Hoppel, K., Bevilacqua, R., Richard, E., Webster, C. R., Elkins, J. W., Hurst, D. F., Romashkin, P. A., and Baumgardner, D. G.: Simulation of ozone depletion in spring 2000 with the Chemical Lagrangian Model of the Stratosphere (CLaMS), J. Geophys. Res., 107, 8295, doi:10.1029/2001JD000456, 2002.

Grooß, J.-U., Günther, G., Müller, R., Konopka, P., Bausch, S., Schlager, H., Voigt, C., Volk, C. M., and Toon, G. C.: Simulation of denitrification and ozone loss for the Arctic winter 2002/2003, Atmos. Chem. Phys., 5, 1437-1448, doi:10.5194/acp-5-14372005, 2005.

Hanson, D. and Mauersberger, K.: Laboratory studies of the nitric acid trihydrate: Implications for the south polar stratosphere, Geophys. Res. Lett., 15, 855-858, 1988.

Hanson, D. R. and Ravishankara, A. R.: Reaction of $\mathrm{ClONO}_{2}$ with $\mathrm{HCl}$ on NAT, NAD and frozen sulfuric acid and hydrolysis of $\mathrm{N}_{2} \mathrm{O}_{5}$ and $\mathrm{ClONO}_{2}$ on frozen sulfuric acid, J. Geophys. Res., 98, 22931-22936, 1993.

Hanson, D. R. and Ravishankara, A. R.: Reactive uptake of $\mathrm{ClONO}_{2}$ onto sulfuric acid due to reaction with $\mathrm{HCl}$ and $\mathrm{H}_{2} \mathrm{O}, \mathrm{J}$. Phys. Chem., 98, 5728-5735, 1994.

Hanson, D. R., Ravishankara, A. R., and Solomon, S.: Heterogeneous reactions in sulfuric acid aerosols: A framework for model calculations, J. Geophys. Res., 99, 3615-3629, 1994.

Hanson, D. R., Ravishankara, A. R., and Lovejoy, E. R.: Reaction of $\mathrm{BrONO}_{2}$ with $\mathrm{H}_{2} \mathrm{O}$ on submicron sulfuric acid aerosol and the implications for the lower stratosphere, J. Geophys. Res., 101, 9063-9069, 1996.
Harris, N. R. P., Lehmann, R., Rex, M., and von der Gathen, P.: A closer look at Arctic ozone loss and polar stratospheric clouds, Atmos. Chem. Phys., 10, 8499-8510, doi:10.5194/acp-10-84992010, 2010

Khosrawi, F., Urban, J., Pitts, M. C., Voelger, P., Achtert, P., Kaphlanov, M., Santee, M. L., Manney, G. L., Murtagh, D., and Fricke, K.-H.: Denitrification and polar stratospheric cloud formation during the Arctic winter 2009/2010, Atmos. Chem. Phys., 11, 8471-8487, doi:10.5194/acp-11-8471-2011, 2011.

Konopka, P., Steinhorst, H.-M., Grooß, J.-U., Günther, G., Müller, R., Elkins, J. W., Jost, H.-J., Richard, E., Schmidt, U., Toon, G., and McKenna, D. S.: Mixing and ozone loss in the 1999-2000 Arctic vortex: Simulations with the three-dimensional Chemical Lagrangian Model of the Stratosphere (CLaMS), J. Geophys. Res., 109, D02315, doi:10.1029/2003JD003792, 2004.

Konopka, P., Engel, A., Funke, B., Müller, R., Grooß, J.U., Günther, G., Wetter, T., Stiller, G., von Clarmann, T., Glatthor, N., Oelhaf, H., Wetzel, G., López-Puertas, M., Pirre, M., Huret, N., and Riese, M.: Ozone loss driven by nitrogen oxides and triggered by stratospheric warmings can outweigh the effect of halogens, J. Geophys. Res., 112, D05105, doi:10.1029/2006JD007064, 2007.

Kuttippurath, J. and Nikulin, G.: A comparative study of the major sudden stratospheric warmings in the Arctic winters 2003/2004-2009/2010, Atmos. Chem. Phys., 12, 8115-8129, doi:10.5194/acp-12-8115-2012, 2012.

Kuttippurath, J., Godin-Beekmann, S., Lefèvre, F., and Goutail, F.: Spatial, temporal, and vertical variability of polar stratospheric ozone loss in the Arctic winters 2004/2005-2009/2010, Atmos. Chem. Phys., 10, 9915-9930, doi:10.5194/acp-10-9915-2010, 2010.

Livesey, N. J., Read, W. G., Froidevaux, L., Lambert, A., Manney, G. L., Pumphrey, H. C., Santee, M. L., Schwartz, M. J., Wang, S., Cofeld, R. E., Cuddy, D. T., Fuller, R. A., Jarnot, R. F., Jiang, J. H., Knosp, B. W., Stek, P. C., Wagner, P. A., and Wu, D. L.: Version 3.3 Level 2 data quality and description document, JPL D-33509, http://mls.jpl.nasa.gov, 2011.

Lowe, D. and MacKenzie, A. R.: Polar stratospheric cloud microphysics and chemistry, J. Atmos. Solar-Terr. Phys., 70, 13-40, 2008.

Mahieu, E., Duchatelet, P., Demoulin, P., Walker, K. A., Dupuy, E., Froidevaux, L., Randall, C., Catoire, V., Strong, K., Boone, C. D., Bernath, P. F., Blavier, J.-F., Blumenstock, T., Coffey, M., De Mazière, M., Griffith, D., Hannigan, J., Hase, F., Jones, N., Jucks, K. W., Kagawa, A., Kasai, Y., Mebarki, Y., Mikuteit, S., Nassar, R., Notholt, J., Rinsland, C. P., Robert, C., Schrems, O., Senten, C., Smale, D., Taylor, J., Tétard, C., Toon, G. C., Warneke, T., Wood, S. W., Zander, R., and Servais, C.: Validation of ACEFTS v2.2 measurements of $\mathrm{HCl}, \mathrm{HF}, \mathrm{CCl} 3 \mathrm{~F}$ and $\mathrm{CCl} 2 \mathrm{~F} 2$ using space-, balloon- and ground-based instrument observations, Atmos. Chem. Phys., 8, 6199-6221, doi:10.5194/acp-8-6199-2008, 2008.

Manney, G. L., Santee, M. L., Rex, M., Livesey, N. J., Pitts, M. C., Veefkind, P., Nash, E. R., Wohltmann, I., Lehmann, R., Froidevaux, L., Poole, L. R., Schoeberl, M. R., Haffner, D. P., Davies, J., Dorokhov, V., Gernandt, H., Johnson, B., Kivi, R., Kyrö, E., Larsen, N., Levelt, P. F., Makshtas, A., McElroy, C. T., Nakajima, H., and Parrondo, M. C.: Unprecedented Arctic ozone loss in 2011, Nature, 478, 469-475, 2011. 
Marti, J. and Mauersberger, K.: A survey and new measurements of ice vapor pressure at temperatures between 170 and $250 \mathrm{~K}$, Geophys. Res. Lett., 20, 363-366, 1993.

Müller, R., Peter, T., Crutzen, P. J., Oelhaf, H., Adrian, G. P., von Clarmann, T., Wegner, A., Schmidt, U., and Lary, D.: Chlorine chemistry and the potential for ozone depletion in the Arctic stratosphere in the winter of 1991/92, Geophys. Res. Lett., 21, 1427-1430, 1994.

Nash, E. R., Newman, P. A., Rosenfield, J. E., and Schoeberl, M. R.: An objective determination of the polar vortex using Ertel's potential vorticity, J. Geophys. Res., 101, 9471-9478, 1996.

Newman, P. A., Harris, N. R. P., Adriani, A., Amanatidis, G. T., Anderson, J. G., Braathen, G. O., Brune, W. H., Carslaw, K. S., Craig, M. S., DeCola, P. L., Guirlet, M., Hipskind, R. S., Kurylo, M. J., Küllmann, H., Larsen, N., Mégie, G. J., Pommereau, J.-P., Poole, L. R., Schoeberl, M. R., Stroh, F., Toon, O. B., Trepte, C. R., and Roozendael, M. V.: An overview of the SOLVE/THESEO 2000 campaign, J. Geophys. Res., 107, 8259, doi:10.1029/2001JD001303, 2002.

Northway, M. J., Gao, R. S., Popp, P. J., Holecek, J. C., Fahey, D. W., Carslaw, K. S., Tolbert, M. A., Lait, L. R., Dhaniyala, S., Flagan, R. C., Wennberg, P. O., Mahoney, M. J., Herman, R. L., Toon, G. C., and Bui, T. P.: An analysis of large $\mathrm{HNO}_{3}$-containing particles sampled in the Arctic stratosphere during the winter of 1999/2000, J. Geophys. Res., 107, 8298, doi:10.1029/2001JD001079, 2002.

Papanastasiou, D. K., Papadimitriou, V. C., Fahey, D. W., and Burkholder, J. B.: UV absorption spectrum of the $\mathrm{ClO}$ dimer $\left(\mathrm{Cl}_{2} \mathrm{O}_{2}\right)$ between 200 and $420 \mathrm{~nm}$, J. Phys. Chem. A, 113, 13711-13726, 2009.

Peter, T. and Grooß, J.-U.: Polar Stratospheric Clouds and Sulfate Aerosol Particles: Microphysics, Denitrification and Heterogeneous Chemistry, in: Stratospheric Ozone Depletion and Climate Change, chap. 4, 108-144, RSC Publishing, 2012.

Pitts, M. C., Thomason, L. W., Poole, L. R., and Winker, D. M.: Characterization of Polar Stratospheric Clouds with spaceborne lidar: CALIPSO and the 2006 Antarctic season, Atmos. Chem. Phys., 7, 5207-5228, doi:10.5194/acp-7-5207-2007, 2007.

Pitts, M. C., Poole, L. R., and Thomason, L. W.: CALIPSO polar stratospheric cloud observations: second-generation detection algorithm and composition discrimination, Atmos. Chem. Phys., 9, 7577-7589, doi:10.5194/acp-9-7577-2009, 2009.

Pitts, M. C., Poole, L. R., Dörnbrack, A., and Thomason, L. W.: The 2009-2010 Arctic polar stratospheric cloud season: a CALIPSO perspective, Atmos. Chem. Phys., 11, 2161-2177, doi:10.5194/acp-11-2161-2011, 2011.

Rex, M., Salawitch, R. J., Deckelmann, H., von der Gathen, P., Harris, N. R. P., Chipperfield, M. P., Naujokat, B., Reimer, E., Allaart, M., Andersen, S. B., Bevilacqua, R., Braathen, G. O., Claude, H., Davies, J., De Backer, H., Dier, H., Dorokhov, V., Fast, H., Gerding, M., Godin-Beekmann, S., Hoppel, K., Johnson, B., Kyrö, E., Litynska, Z., Moore, D., Nakane, H., Parrondo, M. C., Risley Jr., A. D., Skrivankova, P., Stübi, R., Viatte, P., Yushkov, V., and Zerefos, C.: Arctic winter 2005: Implications for stratospheric ozone loss and climate change, Geophys. Res. Lett., 33, L23808, doi:10.1029/2006GL026731, 2006.

Sander, S. P., Abbatt, J., Barker, J. R., Burkholder, J. B., Friedl, R. R., Golden, D. M., Huie, R. E., Kolb, C. E., Kurylo, M. J., Moortgat, G. K., Orkin, V. L., and Wine, P. H.: Chemical ki- netics and photochemical data for use in atmospheric studies, Evaluation Number 17, JPL Publication 10-06, Jet Propulsion Laboratory, California Institute of Technology, Pasadena, http: //jpldataeval.jpl.nasa.gov, 2011.

Santee, M. L., Lambert, A., Read, W. G., Livesey, N. J., Manney, G. L., Cofield, R. E., Cuddy, D. T., Daffer, W. H., Drouin, B. J., Froidevaux, L., Fuller, R. A., Jarnot, R. F., Knosp, B. W., Perun, V. S., Snyder, W. V., Stek, P. C., Thurstans, R. P., Wagner, P. A., Waters, J. W., Connor, B., Urban, J., Murtagh, D., Ricaud, P., Barret, B., Kleinböhl, A., Kuttippurath, J., Küllmann, H., von Hobe, M., Toon, G. C., and Stachnik, R. A.: Validation of the Aura Microwave Limb Sounder $\mathrm{ClO}$ measurements, J. Geophys. Res., 113, D15S22, doi:10.1029/2007JD008762, 2008.

Shi, Q., Jayne, J. T., Kolb, C. E., Worsnop, D. R., and Davidovits, P.: Kinetic model for reaction of $\mathrm{ClONO}_{2}$ with $\mathrm{H}_{2} \mathrm{O}$ and $\mathrm{HCl}$ and $\mathrm{HOCl}$ with $\mathrm{HCl}$ in sulfuric acid solutions, J. Geophys. Res., 106, 24259-24274, 2001.

Solomon, S.: Stratospheric ozone depletion: A review of concepts and history, Rev. Geophys., 37, 275-316, 1999.

Solomon, S.: Interactive comment on "Temperature thresholds for polar stratospheric ozone loss" by K. Drdla and R. Müller, Atmos. Chem. Phys. Discuss., 10, C11119-C11124, 2010.

Solomon, S.: Interactive comment on "Reconciliation of essential process parameters for an enhanced predictability of Arctic stratospheric ozone loss and its climate interactions" by M. von Hobe et al., Atmos. Chem. Phys. Discuss., 12, C11569-C11581, 2012.

Suminska-Ebersoldt, O., Lehmann, R., Wegner, T., Grooß, J.-U., Hösen, E., Weigel, R., Frey, W., Griessbach, S., Mitev, V., Emde, C., Volk, C. M., Borrmann, S., Rex, M., Stroh, F., and von Hobe, M.: ClOOCl photolysis at high solar zenith angles: analysis of the RECONCILE self-match flight, Atmos. Chem. Phys., 12, 1353-1365, doi:10.5194/acp-12-1353-2012, 2012.

Thomason, L. and Peter, T.: Assessment of Stratospheric Aerosol Properties, SPARC Report No. 4, WMO/TD-No. 1295, http: //www.sparc-climate.org, 2006.

Ulanovsky, A. E., Yushkov, V. A., Sitnikov, N. M., and Ravegnani, F.: The FOZAN-II Fast-Response Chemiluminescent Airborne Ozone Analyzer, Instruments and Experimental Techniques, 44, 249-256, 2001.

Voigt, C., Schlager, H., Luo, B. P., Dörnbrack, A., Roiger, A., Stock, P., Curtius, J., Vössing, H., Borrmann, S., Davies, S., Konopka, P., Schiller, C., Shur, G., and Peter, T.: Nitric Acid Trihydrate (NAT) formation at low NAT supersaturation in Polar Stratospheric Clouds (PSCs), Atmos. Chem. Phys., 5, 13711380, doi:10.5194/acp-5-1371-2005, 2005.

Volk, C., Riediger, O., Strunk, M., Schmidt, U., Ravegnani, F., Ulanovsky, A., and Rudakovand, V.: In situ tracer measurements in the tropical tropopause region during APE-THESEO, Eur. Comm. Air Pollut. Res. Report 73, 2000.

von Hobe, M., Grooß, J.-U., Müller, R., Hrechanyy, S., Winkler, U., and Stroh, F.: A re-evaluation of the $\mathrm{ClO} / \mathrm{Cl}_{2} \mathrm{O}_{2}$ equilibrium constant based on stratospheric in-situ observations, Atmos. Chem. Phys., 5, 693-702, doi:10.5194/acp-5-693-2005, 2005.

von Hobe, M., Bekki, S., Borrmann, S., Cairo, F., D’Amato, F., Di Donfrancesco, G., Dörnbrack, A., Ebersoldt, A., Ebert, M., Emde, C., Engel, I., Ern, M., Frey, W., Griessbach, S., Grooß, J.-U., Gulde, T., Günther, G., Hösen, E., Hoffmann, L., Homonnai, V., Hoyle, C. R., Isaksen, I. S. A., Jackson, D. R., Jánosi, 
I. M., Kandler, K., Kalicinsky, C., Keil, A., Khaykin, S. M., Khosrawi, F., Kivi, R., Kuttippurath, J., Laube, J. C., Lefèvre, F., Lehmann, R., Ludmann, S., Luo, B. P., Marchand, M., Meyer, J., Mitev, V., Molleker, S., Müller, R., Oelhaf, H., Olschewski, F., Orsolini, Y., Peter, T., Pfeilsticker, K., Piesch, C., Pitts, M. C., Poole, L. R., Pope, F. D., Ravegnani, F., Rex, M., Riese, M., Röckmann, T., Rognerud, B., Roiger, A., Rolf, C., Santee, M. L., Scheibe, M., Schiller, C., Schlager, H., Siciliani de Cumis, M., Sitnikov, N., Søvde, O. A., Spang, R., Spelten, N., Stordal, F., Suminska-Ebersoldt, O., Viciani, S., Volk, C. M., vom Scheidt, M., Ulanovski, A., von der Gathen, P., Walker, K., Wegner, T., Weigel, R., Weinbuch, S., Wetzel, G., Wienhold, F. G., Wintel, J., Wohltmann, I., Woiwode, W., Young, I. A. K., Yushkov, V., Zobrist, B., and Stroh, F.: Reconciliation of essential process parameters for an enhanced predictability of Arctic stratospheric ozone loss and its climate interactions, Atmos. Chem. Phys. Discuss., 12, 30661-30754, doi:10.5194/acpd-12-30661-2012, 2012.

Wagner, R., Möhler, O., Saathoff, H., Stetzer, O., and Schurath, U.: Infrared spectrum of Nitric Acid Dihydrate: Influence of particle shape, J. Phys. Chem. A, 109, 2572-2581, 2005.

Waters, J. W., Froidevaux, L., Harwood, R. S., Jarnot, R. F., Pickett, H. M., Read, W. G., Siegel, P. H., Coeld, R. E., Filipiak, M. J., Flower, D. A., Holden, J. R., Lau, G. K., Livesey, N. J., Manney, G. L., Pumphrey, H. C., Santee, M. L., Wu, D. L., Cuddy, D. T., Lay, R. R., Loo, M. S., Perun, V. S., Schwartz, M. J., Stek, P. C., Thurstans, R. P., Chandra, K. M., Chavez, M. C., Chen, G.-S., Boyles, M. A., Chudasama, B. V., Dodge, R., Fuller, R. A., Girard, M. A., Jiang, J. H., Jiang, Y., Knosp, B. W., LaBelle, R. C., Lam, J. C., Lee, K. A., Miller, D., Oswald, J. E., Patel, N. C., Pukala, D. M., Quintero, O., Scaff, D. M., Snyder, W. V., Tope, M. C., Wagner, P. A., and Walch, M. J.: The Earth Observing System Microwave Limb Sounder (EOS MLS) on the Aura satellite, IEEE T. Geosci. Remote, 44, 1075-1092, 2006.
Wegner, T., Grooß, J.-U., von Hobe, M., Stroh, F., SuminskaEbersoldt, O., Volk, C. M., Hösen, E., Mitev, V., Shur, G., and Müller, R.: Heterogeneous chlorine activation on stratospheric aerosols and clouds in the Arctic polar vortex, Atmos. Chem. Phys., 12, 11095-11106, doi:10.5194/acp-12-11095-2012, 2012.

WMO: World Meteorological Organization (WMO)/United Nations Environment Programme (UNEP), Scientific assessment of ozone depletion: 2010, Global Ozone Research and Monitoring Project - Report No. 52, 2011.

Wohltmann, I. and Rex, M.: The Lagrangian chemistry and transport model ATLAS: validation of advective transport and mixing, Geosci. Model Dev., 2, 153-173, doi:10.5194/gmd-2-153-2009, 2009.

Wohltmann, I., Lehmann, R., and Rex, M.: The Lagrangian chemistry and transport model ATLAS: simulation and validation of stratospheric chemistry and ozone loss in the winter 1999/2000, Geosci. Model Dev., 3, 585-601, doi:10.5194/gmd-3-585-2010, 2010.

Wolff, M. A., Kerzenmacher, T., Strong, K., Walker, K. A., Toohey, M., Dupuy, E., Bernath, P. F., Boone, C. D., Brohede, S., Catoire, V., von Clarmann, T., Coffey, M., Daffer, W. H., De Mazière, M., Duchatelet, P., Glatthor, N., Griffith, D. W. T., Hannigan, J., Hase, F., Höpfner, M., Huret, N., Jones, N., Jucks, K., Kagawa, A., Kasai, Y., Kramer, I., Küllmann, H., Kuttippurath, J., Mahieu, E., Manney, G., McElroy, C. T., McLinden, C., Mébarki, Y., Mikuteit, S., Murtagh, D., Piccolo, C., Raspollini, P., Ridolfi, M., Ruhnke, R., Santee, M., Senten, C., Smale, D., Tétard, C., Urban, J., and Wood, S.: Validation of $\mathrm{HNO}_{3}, \mathrm{ClONO}_{2}$, and $\mathrm{N}_{2} \mathrm{O}_{5}$ from the Atmospheric Chemistry Experiment Fourier Transform Spectrometer (ACE-FTS), Atmos. Chem. Phys., 8, 3529-3562, doi:10.5194/acp-8-3529-2008, 2008. 